Check for updates

Cite this: RSC Adv., 2018, 8, 22710

Received 17th April 2018 Accepted 25th May 2018

DOI: $10.1039 / c 8 r a 03296 c$

rsc.li/rsc-advances

\section{Recent advances in hydrophilic modification and performance of polyethersulfone (PES) membrane via additive blending}

\author{
Tunmise Ayode Otitoju, Abdul Latif Ahmad (D)* and Boon Seng Ooi
}

The blending of additives in the polyethersulfone (PES) matrix is an important approach in the membrane industry to reduce membrane hydrophobicity and improve the performance (flux, solute rejection, and reduction of fouling). Several (hydrophilic) modifications of the PES membrane have been developed. Given the importance of the hydrophilic modification methods for PES membranes and their applications, we decided to dedicate this review solely to this topic. The types of additives embedded into the PES matrix can be divided into two main categories: (i) polymers and (ii) inorganic nanoparticles (NPs). The introduced polymers include polyvinylpyrrolidone, chitosan, polyamide, polyethylene oxide, and polyethylene glycol. The introduced nanoparticles discussed include titanium, iron, aluminum, silver, zirconium, silica, magnesium based NPs, carbon, and halloysite nanotubes. In addition, the applications of hydrophilic PES membranes are also reviewed. Reviewing the research progress in the hydrophilic modification of PES membranes is necessary and imperative to provide more insights for their future development and perhaps to open the door to extend their applications to other more challenging areas.

\section{Introduction}

Polyethersulfone (PES) is a recognized polymeric material, which is widely employed in the fabrication of membranes for various applications. Due to its high glass transition

School of Chemical Engineering, Engineering Campus, Universiti Sains Malaysia, 14300, Nibong Tebal, Penang, Malaysia. E-mail: chlatif@usm.my; Fax: +6045941013; Tel: $+60-45995999$

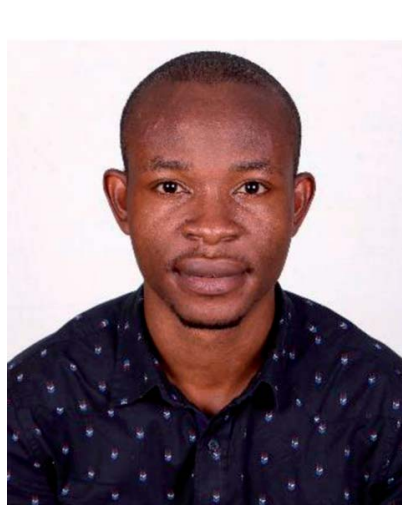

Tunmise Ayode Otitoju received his B. Tech. in Industrial Design (Ceramics) from the Federal University of Technology, Akure, Nigeria, in 2011. He then obtained his M. Sc. in Environmental Management (Waste and Wastewater treatment) from the Universiti Malaysia Sarawak in 2015. He joined as a PhD student in Chemical Engineering (Membrane Technology) under the supervision of Professor Dr Abdul Latif Ahmad at the Universiti Sains Malaysia. His research areas of interest includes composite membrane (ceramic, polymeric, and inorganic membrane) for fouling mitigation, water and wastewater treatment, wastewater engineering. temperature $\left(225^{\circ} \mathrm{C}\right)$, and amorphous and transparent properties, PES possesses a high mechanical and hydrolytic stability, thermal and chemical resistance, and outstanding oxidative characteristics, ${ }^{1}$ making it ideal for the preparation of asymmetric membranes with different surfaces and pore sizes. ${ }^{1-3}$ Asymmetric PES membranes are generally prepared via a phaseseparation method. The final membrane properties and performance are influenced by the composition (additives,

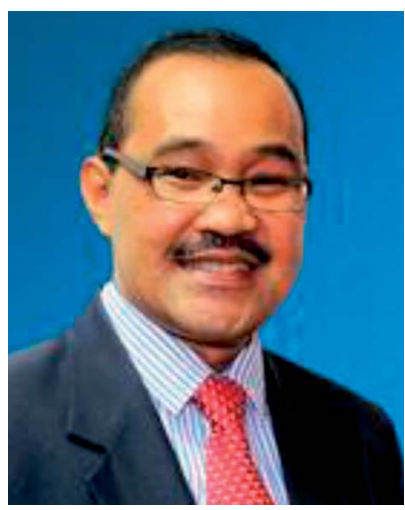

Abdul Latif Ahmad is presently a professor in the School of Chemical Engineering at the Universiti Sains Malaysia. He obtained his B. Eng. in Chemical Engineering from the University of Wales, Swansea, UK, in 1990, He obtained his M.Sc. in Chemical Engineering from the University of Wales, Swansea, UK, in 1991. He thereafter received his $P h D$ in Chemical Engineering from the University of Wales, Swansea, UK in 1995. He was the Dean of School of Chemical Engineering, USM, from 2005-2010 and Research Dean, Science Fundamental Platform from 2010-2012. His research areas includes membrane technology, wastewater engineering, separation process, adsorption technology. 
concentration, and solvent), temperature of the doping solution, the non-solvent or the mixture of non-solvents, and the coagulation bath or the environment. ${ }^{4}$ The risk of the fouling effect due to the high hydrophobicity of PES, especially in protein-contacting applications and aqueous filtrations, limits their wide applications. ${ }^{2,3}$ Numerous research studies have reported efforts to enhance the hydrophilicity of the PES membrane surface..$^{\mathbf{1 , 5}}$

Basically, the water contact angle (WCA) formed between the membrane-liquid boundary and liquid-gas tangent is generally employed to evaluate the hydrophilic properties of the membrane. ${ }^{6}$ Commercial PES membranes are hydrophobic in nature with high mechanical, chemical, and thermal stability. ${ }^{7}$ Usually, these membranes possesses high WCA values and are prone to solute adsorption from various feed streams. It has been well documented that membranes with hydrophilic surfaces are less prone to the fouling effect with microorganisms and organic substances due to: (i) a decreased interaction between the membrane surface and foulant, and (ii) no interaction of hydrogen bonds in the boundary layer between water and the membrane interface. ${ }^{8-10}$ The repulsion of water molecules away from the surface of the hydrophobic PES membrane is a spontaneous process with increasing entropy, and therefore foulant molecules have a tendency to dominate the boundary layer and adsorb onto the PES membrane surface. However, a modified PES membrane with a hydrophilic chain and high surface tension can enhance the formation of hydrogen bonds with the surrounding water molecules. This hydrogen bonding can reduce or prevent the adhesion of foulants on the surface of the PES membrane. ${ }^{\mathbf{1 1 , 1 2}}$ The membrane WCA is related to the zeta potential, surface roughness, and functional groups. ${ }^{\mathbf{1 3 , 1 4}}$ Ref. 15 and 16 demonstrated that an improved membrane hydrophilicity can be favored by increasing the density of the surface hydrophilic-group, including $-\mathrm{NH}_{2}$ and $-\mathrm{OH}$.

Numerous studies on PES membranes have been carried out with the aim to enhance the hydrophilicity and performance, including through an improvement in their preparation process (blending) and by surface modification of the nascent membranes. In surface modification, a hydrophilic layer is

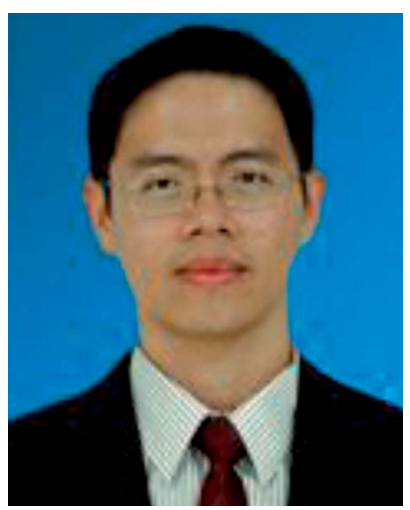

Boon Seng Ooi is presently an associate professor in the School of Chemical Engineering at the Universiti Sains Malaysia. He did his B. Eng. in Chemical Engineering (Bioprocess Engineering) from Universiti Sains Malaysia in 1999. He then obtained his PhD in Chemical Engineering (Membrane Technology) from the Universiti Sains Malaysia in 2005. His current research areas includes functional polymeric membranes, composite membranes for fouling mitigation, product recovery from waste using membrane technology, and integrated and energy efficient membrane technology for water reclamation. formed on the existing PES membrane surface, which can then aid the prevention of contact between the solute and membrane surface, thus reducing the membrane fouling effect. The surface modification can be classified based on two categories, namely chemical or physical modification. In chemical modification, the PES membrane surface is modified through covalent bonding interactions. In this procedure, PES chains are first activated by chemical reaction, followed by the grafting with hydrophilic additives. The use of surface modification may render the hydrophilicity permanent, but may, however, lead to degradation of the PES chains on the membrane surface. ${ }^{17}$ In practice, these methods usually require caustic chemicals, which limits their wide use and long-term stability in membrane applications. Physical modification signifies that the hydrophilic modifiers exist on the PES membrane surface via physical interaction. Here, the blending approach is a versatile and convenient procedure under mild conditions to enhance the hydrophilicity and performance of PES membranes. ${ }^{18,19}$ Blending is a process in which two (or more) inorganic and/or organic materials are physically mixed to obtain the required properties on the membrane. This introduction can be achieved by adding polymer material and inorganic nanofillers into the casting solution. Table 1 presents the advantages and disadvantages of both approaches. Since most of these additives are hydrophilic in nature, they are able to increase the hydrophilicity of the resulting membranes and thus can reduce the fouling effects. Other advantages of blending with hydrophilic additives include an increase in the water flux (WF) due to the enlarged effective membrane surface area and the introduction of additional functional groups. ${ }^{20}$

\section{Embedding polymer materials}

In this approach, hydrophilic organic polymers are dissolved in PES solution. The materials most commonly used include polyvinyl pyrrolidone (PVP), chitosan (CS), polyamide, polyethylene oxide (PEO), and polyethylene glycol (PEG) derivatives due to their reasonable price and high compatibility with PES. ${ }^{21}$ Table 2 shows the progress reported in recent studies on polymeric addition in PES membranes.

One general issue of blending with a polymer is the elution of this polymer and poor compatibility with the PES matrix. ${ }^{17}$ To address this issue, some researchers have looked into the use of amphiphilic copolymers as well as amphiphilic copolymers containing PES chains with hydrophobic parts as modifiers. Amphiphilic modifiers contain hydrophilic and hydrophobic properties, which means they are able to interact with the hydrophobic PES polymer, which is totally insoluble in water, and are also able to interact with hydrophobic PES polymers. The hydrophobic chains guarantees the compatibility with the host PES polymer, while the hydrophilic chains are enriched onto the membrane pore during phase inversion due to a segregation effect, thus, providing a high coverage of hydrated side chains anchored by a hydrophobic backbone entangled with the PES bulk that is water insoluble. ${ }^{\mathbf{3 0 , 3 1}}$ Moreover, by controlling the ratio of hydrophobicity and enhancing the hydrophilicity during the membrane casting, desirable 
Table 1 Advantages and disadvantages of incorporating polymer and inorganic additives in the PES membrane matrix

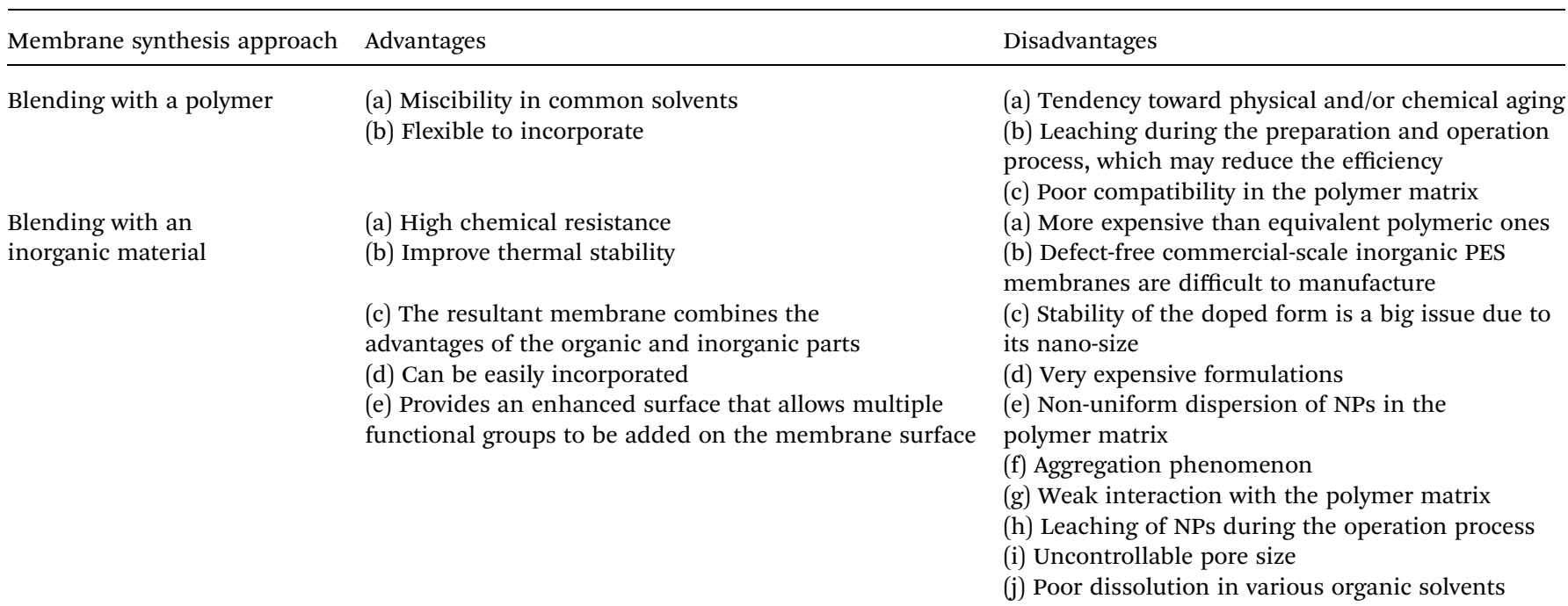

Table 2 Progress of recent studies for the fabrication of hydrophilic PES-polymer blend membranes

\begin{tabular}{llll}
\hline Additive & Additive loadings $(w t \%)$ & Hydrophilic change $\left(^{\circ}\right)$ & Ref. \\
\hline PEG & 2 & $\sim 70$ to $\sim 57$ & 22 \\
PEG/PVP & - & 85 to 59 & 23 \\
PVP 40K & 4 & 71 to 47 & 24 \\
PVP & 5 & $\sim 63$ to $\sim 56$ & 25 \\
P31R1 & 5 & $\sim 63$ to 44 & 25 \\
PVP & 2 & $\sim 76$ to $\sim 71$ & 26 \\
T904 & 5 & $\sim 63$ to $\sim 52$ & 25 \\
PVP & 2 & $\sim 76$ to $\sim 71$ & 27 \\
PA-6 & 2 & $\sim 76$ to 68 & 26 \\
PVP & 10 & 70 to 51 & 28 \\
NPhthCs & 0.9 & 61 to 56 & 29
\end{tabular}

membrane performance properties can be achieved, such as a higher solute rejection, fouling resistance, and permeability. ${ }^{32}$ Table 3 show a summary of hydrophilic PES-amphiphilic copolymer blend membranes.

Generally, it has been well documented that these copolymers have better compatibility with the PES bulk, and could be used as modifiers to enhance the hydrophilicity, antifouling properties, and performance of PES membranes. ${ }^{41-44}$

\section{Embedding inorganic materials}

Apart from introducing polymers and copolymers, inorganic NPs are another promising modifier. The addition of inorganic NPs with the PES matrix has become an attractive approach for the fabrication of polymeric membranes and has captured much attention in recent times. ${ }^{45-50}$ Much of the bulk of the research has been carried out on the preparation of composite PES-inorganic membranes by the addition of inorganic NPs. For instance, the presence of dispersed inorganic NPs in the membrane matrix has been reported to improve the membrane performance and properties, particularly by: (a) increasing the permeability due to the larger effective membrane surface area of NPs; (b) inducing a membrane with the functional properties of the nanomaterials; ${ }^{20}$ (c) enhancing the mass transfer in the membrane pre-evaporation process; ${ }^{51}$ (d) improving a membrane's hydrophilicity as well as fouling resistance properties; ${ }^{\mathbf{4 6 5}}$ (e) improving the thermal and mechanical properties. ${ }^{53-58}$ To date, many types of inorganic materials have been incorporated as additives in the PES matrix, including titanium dioxide, silicon dioxide, carbon nanotubes, halloysite nanotubes, manganese oxide, cellulose nanocrystals, graphene oxide, silver NPs, zirconia, zinc oxide, alumina, and metal-organic frameworks. However, there are two ways to introduce these NPs into the PES membrane during the preparation process: blending them in a coagulation bath or in the polymer solution. Compared to the blending of nanofillers in a coagulation bath, blending the nanoparticles in the polymer solution has been the dominant method. The discussion below introduces the incorporation of inorganic additives in the PES matrix.

\section{Embedding titanium dioxide NPs}

Titanium dioxide $\left(\mathrm{TiO}_{2}\right)$ has been the major focus of quite a significant number of studies in recent and past years, due to its photocatalytic effects, which aid in killing bacteria and decomposing organic chemicals, relative cheapness, chemical stability, optical property, and non-toxicity. ${ }^{49,59-65}$ As one of the most investigated NPs, when $\mathrm{TiO}_{2}$ NPs are dispersed in the PES matrix, the membrane hydrophilicity and antifouling ability can be enhanced. On this basis, lots of effort has been devoted to investigating the effect of $\mathrm{TiO}_{2}$ NPs to improve the PES membrane hydrophilicity. For instance, ref. 66 introduced $\mathrm{TiO}_{2}$ to produce $\mathrm{PES}-\mathrm{TiO}_{2}$ membranes and found that modification with $0.2 \mathrm{wt} \%$ led to an improved hydrophilicity as WCA decreased from $75.2^{\circ}$ to $66.4^{\circ}$. Another study by ref. 67 showed a decrease in WCA from $72.2^{\circ}$ to $57.4^{\circ}$ when the content of $\mathrm{TiO}_{2}$ 
Table 3 Progress in recent studies in the fabrication of hydrophilic PES-amphiphilic copolymer blend membranes

\begin{tabular}{|c|c|c|c|c|}
\hline Additive & Synthesis of the additive & Additive loadings (wt\%) & Hydrophilic change $\left(^{\circ}\right)$ & Ref. \\
\hline PDMAEMA & RAFT & 20 & $\sim 84$ to 56 & 33 \\
\hline PNIPAAm & RAFT & 20 & $\sim 84$ to $\sim 71$ & 33 \\
\hline PSf- $g$-POEM & ATRP & 5 & 85 to 52 & 35 \\
\hline PS- $b$-PAA & Free radical polymerization & - & $\sim 70$ to $\sim 50$ & 36 \\
\hline MF- $g$-PEG $6 \mathrm{k}$ & Etherification & 0.36 & - & 37 \\
\hline PVP- $b$-PMMA- $b$-PVP & RAFT & 5 & 73 to 60 & 39 \\
\hline PES- $g$-PSBMA & RAFT and quaternization & 15 & 90 to 60 & 40 \\
\hline
\end{tabular}

was $1 \mathrm{wt} \%$ in the PES matrix. The result by ref. 68 showed an improved hydrophilicity of $54.2^{\circ}$ when the content of NPs was $0.1 \mathrm{wt} \%$ as compared to an unmodified membrane $\left(65.5^{\circ}\right)$. Ref. 69 observed a significant reduction in WCA from $71.9^{\circ}$ to $59.6^{\circ}$ when the content of $\mathrm{TiO}_{2}$ NPs was $2 \mathrm{wt} \%$. Ref. 70 also reported a $\mathrm{PES} / \mathrm{TiO}_{2}$ composite membrane that resulted in an enhanced hydrophilicity of $44.1^{\circ}$ upon the introduction of $0.4 \mathrm{wt} \% \mathrm{TiO}_{2}$ as compared to the neat membrane of $52.3^{\circ}$. Ref. 71 introduced a mechanically modified $\mathrm{TiO}_{2}$ into the PES matrix and observed a reduction in WCA from $64^{\circ}$ to $56^{\circ}$ when the concentration of the modified NPs was increased to $2 \mathrm{wt} \%$. Furthermore, the hydrophilicity was improved to $50^{\circ}$ when mechanically and chemically modified $\mathrm{TiO}_{2}$ was introduced. This result was similar to that reported in the study by ref. 69 , who observed an improved hydrophilicity from $71.9^{\circ}$ to $62.3^{\circ}$ when the content of a mechanically and chemically modified $\mathrm{TiO}_{2}$ was $2 \mathrm{wt} \%$.

\section{Embedding silica $\left(\mathrm{SiO}_{2}\right)$ NPs}

The addition of $\mathrm{SiO}_{2}$ NPs has been investigated intensively and proven ideal as an additive for PES membranes due to their many useful properties, such as fine suspendability in aqueous solution, relatively environmentally inert, being thermally and chemically stable with a large surface area (SA), and highly miscible. ${ }^{72}$ A significant number of works have been reported on their addition into the PES matrix and they have been found to be a promising additive for enhanced hydrophilic PES membranes. For example, ref. 73 introduced a $\mathrm{SiO}_{2} / \mathrm{PES}$ membrane, which showed a significant reduction in WCA from $78.6^{\circ}$ to $58.1^{\circ}$ when the $\mathrm{SiO}_{2}$ content was $2 \mathrm{wt} \%$ in the matrix. Ref. 74 prepared a PES nano-SiO $\mathrm{S}_{2}$ membrane by introducing monodisperse silica spheres in the PES matrix, which led to an improvement in hydrophilicity with WCA decreasing from $52.4^{\circ}$ to $45.7^{\circ}$ when the content of NPs was $0.3 \mathrm{wt} \%$. Ref. 75 synthesized a series of amine-functionalized mesostructured silica (SBA-15) particles and then incorporated these in the PES matrix. The synthesis of the different organically functionalized SBA-15 particles was similar to that for the conventional SBA-15 except for the addition of a certain amount of selected organosilanes $1 \mathrm{~h}$ after adding tetraethyl orthosilicate (TEOS). In the case of the amino-functionalized silica materials, [3-(2-aminoethylamino) propyl] trimethoxysilane (AEAPTMS) and (3-aminopropyl) trimethoxysilane (APTMS) were used as an organosilane with an organosilane/TEOS molar ratio of $15 \%$. In the case of the carboxylic-functionalized silica materials, carboxyethylsilanetriol sodium salt (CES) was used as a carboxylic group source with organosilane/TEOS molar ratios of $15 \%$ and $30 \%$. The WCA of the neat membrane and the PES/ mesostructured SBA-15 were $70.3^{\circ}$ and $64.7^{\circ}$, respectively. However, upon the introduction of $0.6 \mathrm{wt} \%$ SBA-15/CES-15, SBA15/AEAPTMS-15, and SBA-15-APTMS-15, the WCA decreases to $63^{\circ}, 61.7^{\circ}, 58.1^{\circ}$, and $55^{\circ}$, respectively. Ref. 76 prepared a hydrophilic hollow mesoporous silica sphere (HMSS) prepared via a surfactant-assembly sol-gel route, which was then blended into PES membranes to fabricate a mixed matrix membrane. The WCA of the pure PES membrane was $76.8^{\circ}$, indicating a strong intrinsic hydrophobicity of the pure PES membrane. However, with the increase in HMSS loading (up to $1.5 \%$ ), the WCA of the PES composite membrane decreased to 63. $8^{\circ}$. Ref. 77 embedded a $N$-halamine-modified $\mathrm{SiO}_{2}$ in the PES

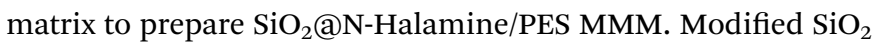
NPs grafted with $N$-halamine were obtained via a three-step reaction process (Fig. 1). Their result showed an improved hydrophilicity with a WCA of $70.6^{\circ}$ using $5 \mathrm{wt} \%$ of modified NPs, which was lower than the neat membrane WCA of $90.7^{\circ}$.

\section{Embedding zinc oxide NPs}

Zinc oxide $(\mathrm{ZnO})$ is another compound that has excellent electrical, optical, chemical, and mechanical properties, including antimicrobial activity. ${ }^{78-80}$ With its low cost and increased surface-to-volume ratio, $\mathrm{ZnO}$ is a potential NP that could meet the demand for the fabrication of a lower-cost and efficient membrane. For example, ref. 81 prepared a PES ZnO HF membrane by introducing ZnO NPs in the PES matrix, which led to an improvement in the hydrophilicity, with WCA decreasing from $70^{\circ}$ to $58^{\circ}$ when the content of NPs was $3.62 \mathrm{wt} \%$. Ref. 82 


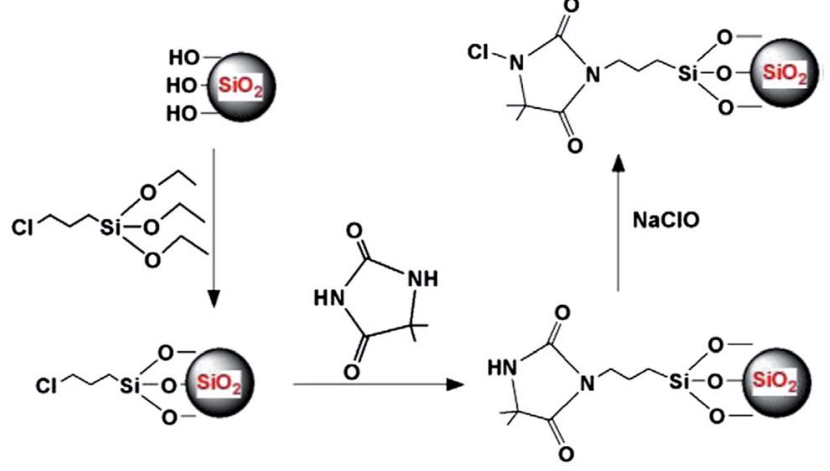

Fig. 1 Basic principles of the reactions with modified $\mathrm{SiO}_{2}{ }^{77}$

observed a significant reduction in WCA from $79.92^{\circ}$ to $62.92^{\circ}$ when the content of ZnO NPs was $0.3 \mathrm{wt} \%$. Ref. 83 also observed a significant reduction in WCA from $71.4^{\circ}$ to $57.7^{\circ}$ when the content of $\mathrm{ZnO}$ NPs was $10 \mathrm{wt} \%$. Ref. 84 prepared and compared two nano-ZnO (ZnO NPs and ZnO nanorod) and then introduced them in the PES matrix. The ZnO nanoparticles were synthesized by co-precipitation technique, while $\mathrm{ZnO}$ nanorods were synthesized by the sol-gel method. In their study, the hydrophilicity of the $\mathrm{ZnO}$-blended membranes rose to $60^{\circ}$ at $0.1 \mathrm{wt} \%$ and reached $54^{\circ}$ when the ZnO NPs were replaced with $\mathrm{ZnO}$ nanorods as compared to the neat membrane of $77.9^{\circ}$. Ref. 85 synthesized a chitosan (CS)-modified ZnO NPs using chemical precipitation prior to doping in the PES matrix to prepare a PES/CS-ZnO NPs membrane, which resulted to an improved hydrophilicity with the WCA declining from $60.73^{\circ}$ for the neat membrane to $40.33^{\circ}$ when the content of CS-ZnO was 15 wt \%. Ref. 86 presented PES ultrafiltration membranes blended with different contents of the $\mathrm{CuO} / \mathrm{ZnO}$ nanocomposite (CZN). In their study, CZN was prepared through a facile onestep homogeneous co-precipitation method at a low temperature (Fig. 2). Their results showed an improve hydrophilicity of $65.5^{\circ}$ against $70.2^{\circ}$ for the neat membrane at an optimal content of CZN $(0.2 \mathrm{wt} \%)$.

\section{Embedding zirconium dioxide NPs}

Zirconium dioxide $\left(\mathrm{ZrO}_{2}\right)$, or zirconia, is a white crystalline oxide of zirconium with excellent chemical stability, melting point, good mechanical properties, and strong anti-corrosion. Zirconia membranes are known to be chemically more stable than alumina and titania PES membranes, and are more suitable for liquid phase applications under harsh conditions. ${ }^{\mathbf{8 8}}$ For instance, ref. 70 presented $\mathrm{ZrO}_{2}$-entrapped membranes, which showed a slight reduction in WCA from $52.23^{\circ}$ to $48.86^{\circ}$ when the content of NPs was $0.4 \mathrm{wt} \%$. In a study by ref. 89 , hydrous $\mathrm{ZrO}_{2}$ sol was synthesized by the addition of an anion-exchange resin in $\mathrm{N}, \mathrm{N}$-dimethylformamide solvent containing zirconyl chloride and then doped in the PES matrix to prepare a $\mathrm{ZrO}_{2} /$ PES composite membrane, which significantly led to a significant reduction in WCA from $73.6^{\circ}$ to $52.3^{\circ}$ at an optimal content of $1 \mathrm{wt} \%$.

\section{Embedding aluminum oxide NPs}

Similar to other metal oxide NPs, aluminum oxide $\left(\mathrm{Al}_{2} \mathrm{O}_{3}\right)$ NPs have attracted great attention in membrane technology for the development of nanocomposite (NC) PES membranes with enhanced properties. Ref. 90 introduced $\mathrm{Al}_{2} \mathrm{O}_{3}$ to produce PES/ $\mathrm{Al}_{2} \mathrm{O}_{3}$ membranes and found that modification with $0.1 \mathrm{wt} \%$ led to an improved hydrophilicity as the WCA decreased from $74.1^{\circ}$ to $64.3^{\circ}$. Another study by ref. 70 showed a decrease in WCA from $52.3^{\circ}$ to $37.8^{\circ}$ when the content of $\mathrm{Al}_{2} \mathrm{O}_{3}$ was $0.4 \mathrm{wt} \%$ in the PES matrix.

\section{Embedding iron oxide-based nanoparticles}

The unique features of iron oxide-based nanoparticles (Fe-NPs), mainly magnetite $\left(\mathrm{Fe}_{3} \mathrm{O}_{4}\right)$, have encouraged many researchers to investigate these engineered magnetic NPs in the synthesis of PES composite membranes. The addition of Fe-NPs has been extensively introduced in the PES matrix to produce composite membranes. For instance, ref. 91 prepared a PES/Fe-NP HF membrane by introducing magnetite NPs in the PES matrix, which led to an improvement in hydrophilicity with the WCA decreasing from $62.22^{\circ}$ to $49.27^{\circ}$ when the content of NPs was $2 \mathrm{wt} \%$. Ref. 92 also presented four sets of PES/NC membranes, such as trisodium citrate-treated $\mathrm{Fe}_{3} \mathrm{O}_{4}, \mathrm{Fe}_{3} \mathrm{O}_{4} / \mathrm{SiO}_{2}, \mathrm{Fe}_{3} \mathrm{O}_{4} / \mathrm{SiO}_{2}$ amine, and $\mathrm{Fe}_{3} \mathrm{O}_{4} / \mathrm{SiO}_{2}$-metformine (Met). $\mathrm{Fe}_{3} \mathrm{O}_{4} / \mathrm{SiO}_{2}$ was prepared by the Stober method, while the surface functionalization of $\mathrm{Fe}_{3} \mathrm{O}_{4} / \mathrm{SiO}_{2} \mathrm{NP}$ was achieved by using APTES as a silylation agent (Fig. 3). The WCA of the neat membrane was $78^{\circ}$. However, upon the introduction of $0.1 \mathrm{wt} \% \mathrm{Fe}_{3} \mathrm{O}_{4} / \mathrm{SiO}_{2}$-amine, $0.1 \mathrm{wt} \%$ trisodium citrate-treated $\mathrm{Fe}_{3} \mathrm{O}_{4}, 0.1$ wt $\% \mathrm{Fe}_{3} \mathrm{O}_{4} / \mathrm{SiO}_{2}$ Met, or $0.1 \mathrm{wt} \% \mathrm{Fe}_{3} \mathrm{O}_{4} / \mathrm{SiO}_{2}$, the WCA decreased to $75^{\circ}, 72^{\circ}, 69^{\circ}$, or $67^{\circ}$, respectively.

Ref. 93 reported six sets of $\mathrm{PES} / \mathrm{NC}$ membranes, such as magnetic-treated $\quad \mathrm{Fe}_{3} \mathrm{O}_{4} \quad\left(\mathrm{~m}-\mathrm{Fe}_{3} \mathrm{O}_{4}\right)$, magnetic-treated polyaniline-coated $\mathrm{Fe}_{3} \mathrm{O}_{4}$ (m-PANI/ $\left.\mathrm{Fe}_{3} \mathrm{O}_{4}\right)$, magnetic-treated $\mathrm{Fe}_{3} \mathrm{O}_{4}$-coated multi-walled carbon nanotubes (m-MWCNT/ $\left.\mathrm{Fe}_{3} \mathrm{O}_{4}\right)$, untreated $\mathrm{Fe}_{3} \mathrm{O}_{4}$, PANI-coated $\mathrm{Fe}_{3} \mathrm{O}_{4}\left(\mathrm{PANI} / \mathrm{Fe}_{3} \mathrm{O}_{4}\right)$, and

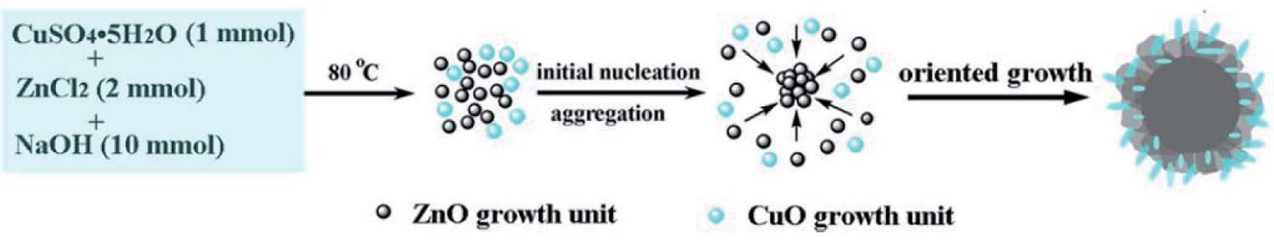

Fig. 2 Schematic illustration of the formation process of CZN. ${ }^{87}$ 
(a)

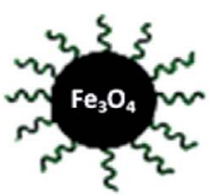

(c)

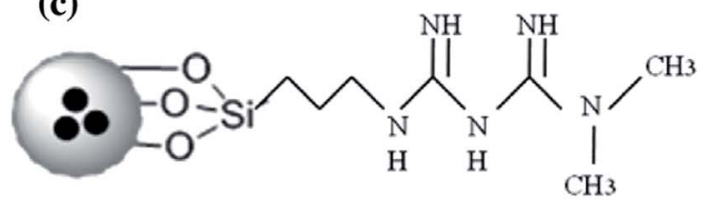

(b)
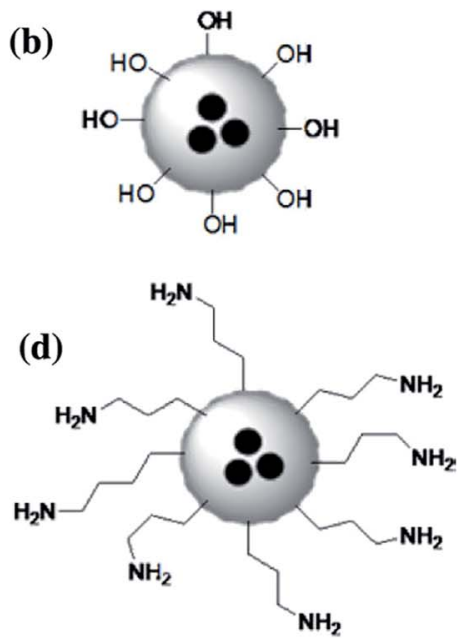

Fig. 3 Schematic of (a) $\mathrm{Fe}_{3} \mathrm{O}_{4}$ treated with trisodium citrate, (b) $\mathrm{Fe}_{3} \mathrm{O}_{4} / \mathrm{SiO}_{2}$, (c) $\mathrm{Fe}_{3} \mathrm{O}_{4} / \mathrm{SiO}_{2}-\mathrm{Met}$, and (d) $\mathrm{Fe}_{3} \mathrm{O}_{4} / \mathrm{SiO}_{2}-\mathrm{amine} \mathrm{NPs}^{92}$

$\mathrm{Fe}_{3} \mathrm{O}_{4}$-coated MWCNT (MWCNT/ $\left.\mathrm{Fe}_{3} \mathrm{O}_{4}\right)$ membranes. For magnetic field induced casting, the casting was carried out under a magnetic field ( 0.1 Tesla) at a distance of $4 \mathrm{~cm}$ (Fig. 4 ). The WCA of the neat membrane was $71.45^{\circ}$. However, upon the introduction of $0.1 \mathrm{wt} \% \mathrm{MWCNT} / \mathrm{Fe}_{3} \mathrm{O}_{4}, 0.1 \mathrm{wt} \% \mathrm{~m}-\mathrm{MWCNT} /$ $\mathrm{Fe}_{3} \mathrm{O}_{4}, 0.1 \mathrm{wt} \%$ untreated $\mathrm{Fe}_{3} \mathrm{O}_{4}, 0.1 \mathrm{wt} \% \mathrm{~m}-\mathrm{Fe}_{3} \mathrm{O}_{4}, 0.1 \mathrm{wt} \%$ $\mathrm{PANI} / \mathrm{Fe}_{3} \mathrm{O}_{4}$, or $0.1 \mathrm{wt} \% \mathrm{~m}-\mathrm{PANI} / \mathrm{Fe}_{3} \mathrm{O}_{4}$, the WCA decreased to $67.06^{\circ}, 60.24^{\circ}, 56.16^{\circ}, 53.38^{\circ}, 51.53^{\circ}$, or $51.12^{\circ}$, respectively.

\section{Embedding silver nanoparticles}

Within the wide range of commercially available nanoscale materials, silver nanoparticles (AgNPs) have also received a great deal of attention. AgNPs have unique properties (such as extremely large surface-to-volume ratio, antimicrobial, optical, and electrical properties), making the NP able to serve as a sustained local supply of $\mathrm{Ag}^{+}$ions in membranes, and so it can prevent bacterial and solute adhesion onto the membrane surface. ${ }^{\mathbf{9 4 - 9 6}}$ Several preparation techniques have been reported for the synthesis of silver NPs; notable examples include photochemical methods, gamma irradiation, laser ablation, microwave processing, electron irradiation, biological synthetic methods, and chemical reduction..$^{95}$ The effects of AgNPs on the final membrane hydrophilicity have been investigated in many studies. A study by ref. ${ }^{97}$ showed a decrease in WCA from $71^{\circ}$ to

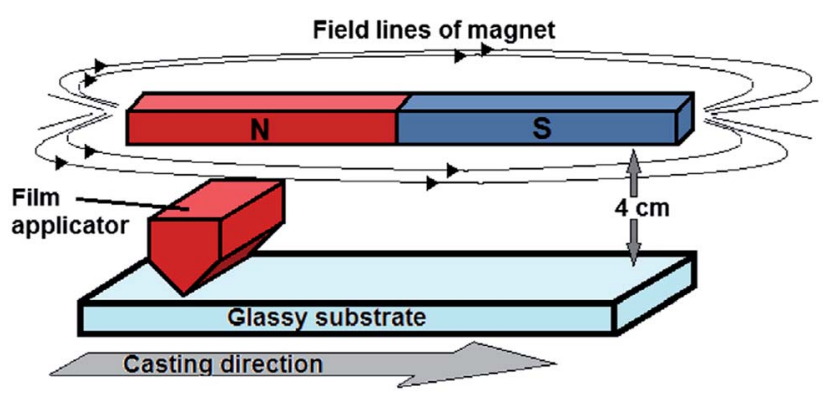

Fig. 4 Scheme of casting under a magnetic field. ${ }^{93}$ $41^{\circ}$ when the content of AgNP was $0.03 \mathrm{wt} \%$ in the PES matrix. Ref. 98 fabricated antibacterial PES/Ag nanocomposite membranes and reported an improvement in surface hydrophilicity from $59.85^{\circ}$ to $40.29^{\circ}$ when the AgNP concentration was $0.5 \mathrm{wt} \%$. In another study by ref. 99, $n$-Ag NPs were prepared by a bacteria-mediated biosynthesis method (Fig. 5) and then introduced to produce the resulting composite membrane. The resulting PES membrane showed an improved hydrophilicity of $65^{\circ}$ upon doping with $1.5 \mathrm{wt} \%$ NPs as compared to the neat membrane showing a value of $88^{\circ}$. This was associated as being due to the higher affinity or intrinsic nature of $n$-Ag with the water molecules.

\section{Embedding graphene oxide NPs}

Graphene oxide (GO), a two-dimensional carbon material, has received tremendous attention due to the presence of abundant $\mathrm{O}_{2}$-containing functional groups (such as carboxyl, epoxy, hydroxyl, and carbonyl groups), fantastic chemical stability, high strength, superior electron transport, low thickness, high flexibility and a negatively charged surface, innocuity, high surface area, and good miscibility with polymers. ${ }^{100-113}$ The existence of these groups makes GO possess good

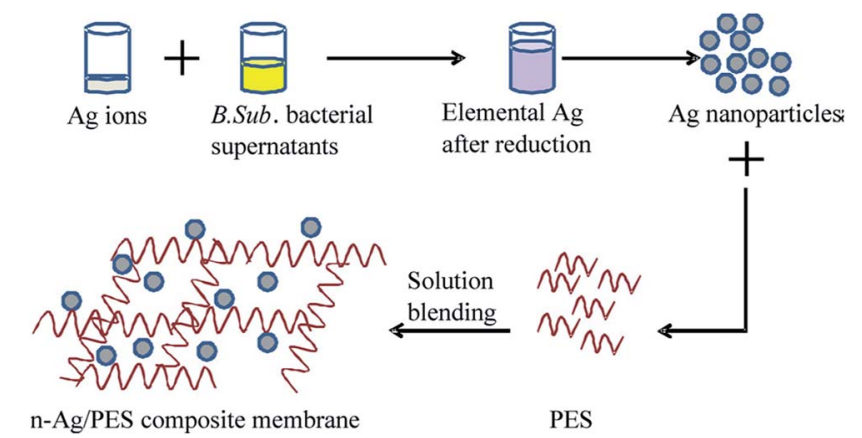

Fig. 5 Schematic representation of the preparation of $\mathrm{PES} / n-\mathrm{Ag}$ composite membranes. ${ }^{99}$ 
Table 4 Progress in recent studies in the fabrication of hydrophilic $\mathrm{PES} / \mathrm{GO}$ nanocomposite membranes

\begin{tabular}{|c|c|c|c|}
\hline Additive & Filler loadings (wt\%) & Hydrophilic change $\left(^{\circ}\right)$ & Ref. \\
\hline GO & 0.3 & 72 to $\sim 55$ & 117 \\
\hline GO/T904 & 0.3 & 72 to 54 & 117 \\
\hline GO NS & 0.5 & 65 to 53 & 118 \\
\hline GO/PAA & 1 & $\sim 71$ to 58 & 119 \\
\hline UiO-66@GO & 3.0 & $\sim 86$ to 60 & 120 \\
\hline GO & 3.0 & $\sim 86$ to 72 & 120 \\
\hline Partially $\mathrm{rGO} / \mathrm{TiO}_{2}$ & 0.1 & $\sim 66$ to 56 & 68 \\
\hline GO & 0.1 & $\sim 66$ to $\sim 59$ & 68 \\
\hline GO-ZnO & 0.1 & $\sim 78$ to $\sim 54$ & 121 \\
\hline HPEI-GO & 5 & $\sim 86$ to 63 & 114 \\
\hline
\end{tabular}

hydrophilicity, is easy to be modified, and has the capability of dispersion in water to yield a prolonged, stable suspension..$^{\mathbf{1 1 4}}$ All these factors make it more appropriate for the hydrophilic modification of PES membranes. ${ }^{115,116}$ On this basis, a large amount of work has been devoted to developing GO/PES NC membranes and their summaries are shown in Table 4.

\section{Embedding CNTs}

Carbon nanotubes (CNTs) are a member of the fullerene structural family and consist of six-membered carbon rings in the honeycomb lattice relative to the axis of the nanotubes (NT). ${ }^{122}$ The pioneer discovery of CNTs by Lijima ${ }^{123}$ has opened up new directions for many applications. CNTs have the ability to interact and alter the physico-chemical properties of the membrane. ${ }^{\mathbf{1 2 4}}$ This property coupled with their high specific surface area with low density, exceptional mechanical properties, nanoscale dimensions and highly precise diameters, high thermal stability, very low frictional coefficients on their internal surface, high strength-to weight ratio, formation of highly porous structures, and chemical stability makes CNTs a promising candidate for complementing or substituting conventional NPs in the fabrication of new generation nanocomposite membranes. ${ }^{\mathbf{1 2 5 - 1 3 8}}$ The excellent mechanical properties of CNTs arise from the presence of $\mathrm{C}-\mathrm{C}$ bonds in the graphite layer, which are most probably the strongest chemical bonds known in nature. CNTs can be synthesized either as a series of shells of different diameters spaced around a common axis, called multi-walled carbon nanotubes, MWCNTs (consisting of up to 10-100 carbon shells), or as singular tubes, called single-walled carbon nanotubes (SWCNTs). ${ }^{139}$ The former are of particular interest over the latter due to their availability in larger quantities and relatively low cost as a result of their more advanced stage in commercial production.

The most crucial problem when using CNTS is the poor dissolution and dispersion of synthesized CNTs in various organic solvents and different polymers as well as their weak interaction with the polymer matrix. ${ }^{\mathbf{1 4 0 - 1 4 3}}$ Moreover during CNTs preparation, the presence of metal catalytic particles and

Table 5 Progress in recent studies in the fabrication of hydrophilic PES/CNTs nanocomposite membranes

\begin{tabular}{|c|c|c|c|c|}
\hline CNTs $(20 \mathrm{~nm})$ & - & 0.1 & $\sim 63$ to $\sim 55$ & 172 \\
\hline Carboxyl-functionalized SWCNT & - & 0.025 & $\sim 70$ to $\sim 62$ & 173 \\
\hline PCA-functionalized MWCNT & In situ polymerization reaction & 0.1 & 75 to 49 & 174 \\
\hline PAA-functionalized MWCNT & In situ polymerization reaction & 0.1 & 75 to $\sim 58$ & 174 \\
\hline MWCNT & - & 0.1 & 75 to 65 & 174 \\
\hline $\mathrm{NH}_{2}$-MWCNTs & Covalent-functionalization & 0.045 & $\sim 65$ to $\sim 56$ & 176 \\
\hline PCL modified MWCNTs & With $\mathrm{Sn}(\mathrm{Oct})_{2}$ & 3 & $\sim 67$ to 57 & 177 \\
\hline Amine-functionalized MWCNTs & Strong acids $\left(\mathrm{H}_{2} \mathrm{SO}_{4} / \mathrm{HNO}_{3}\right)$ and 1,3-phenylenediamine & 1 & 69 to $\sim 52$ & 1 \\
\hline MWCNT-OH & - & 0.8 & $\sim 77$ to $\sim 74$ & 178 \\
\hline MWCNT-COOH & - & 0.8 & $\sim 77$ to 59 & 178 \\
\hline Functionalized MWCNT & Non-covalent modification with SLS & 2 & $\sim 79$ to 51 & 182 \\
\hline $\begin{array}{l}\text { Acid-oxidized MWCNTs coated } \\
\text { by anatase } \mathrm{TiO}_{2}\end{array}$ & Precipitation of $\mathrm{TiCl}_{4}$ precursor & 0.1 & 66 to $\sim 63$ & 183 \\
\hline ZnO coated MWCNTs & Coating & 0.5 & 68 to 57 & 184 \\
\hline PAA grafted MWCNTs & $\begin{array}{l}\text { In situ polymerization of AA in aqueous solution } \\
\text { in the presence of KPS as initiator and EG as cross-linker }\end{array}$ & 0.1 & $\sim 73$ to $\sim 57$ & 185 \\
\hline Ag-coated MWCNTs & $\mathrm{Ag}$ & 0.9 & 64 to 51 & 186 \\
\hline MWCNTs-PANI & In situ polymerization in the presence of aniline and APS & 2 & 73 to $\sim 53$ & 187 \\
\hline $\mathrm{Fe}-\mathrm{Ag} /$ functionalized MWCNT & Acid and then Fe and Ag NPs & 1 & 75 to $\sim 44$ & 188 \\
\hline TETA-MWCNTs & - & 0.4 & $\sim 68$ to 60 & 189 \\
\hline Acid-functionalized MWCNTs & $\mathrm{HNO}_{3}$ and $\mathrm{H}_{2} \mathrm{SO}_{4}$ & 0.5 & $\sim 70$ to $\sim 57$ & 190 \\
\hline
\end{tabular}


amorphous carbon, as impurities, could add an additional burden to the intended application. ${ }^{\mathbf{1 4}}$ These factors are important in the utilization of additives in polymer composites as well as CNTs. ${ }^{\mathbf{1 4 5 , 1 4 6}}$ Therefore, the purification and functionalization of CNTs could be established to negate the hydrophobic nature of CNTs and to broaden their promising scope. For this reason, different linking groups, e.g., $-\mathrm{NH}_{2},-\mathrm{SO}_{3} \mathrm{H}$, $-\mathrm{COOH},-\mathrm{OH}$, or $-\mathrm{CONH}_{2}$ could be introduced to the CNTs surface to facilitate linking different metal clusters to the nanotubes surface via polymer wrapping, covalent attachment (grafting), and non-covalent attachment (adsorbing). ${ }^{\mathbf{1 2 2 , 1 4 6 - 1 5 9}}$ The amine $\left(\mathrm{NH}_{2}\right)$ group has a wealth of chemistry and high reactivity with many chemicals, such as polymers. ${ }^{\mathbf{1 6 0 - 1 6 2}}$ After modification, they become soluble in different solvents, as well as contain functional groups, which turn them into a multidisciplinary materials in other applications. The functionalization by chemical oxidation of CNTs is the most commonly used method, which breaks the $\mathrm{sp}^{2}$ hybrid carbon bonds on the sidewalls, and attaches carboxyl/hydroxyl groups to the CNTs. ${ }^{163}$ Functionalized CNTs can enhance the properties of PES

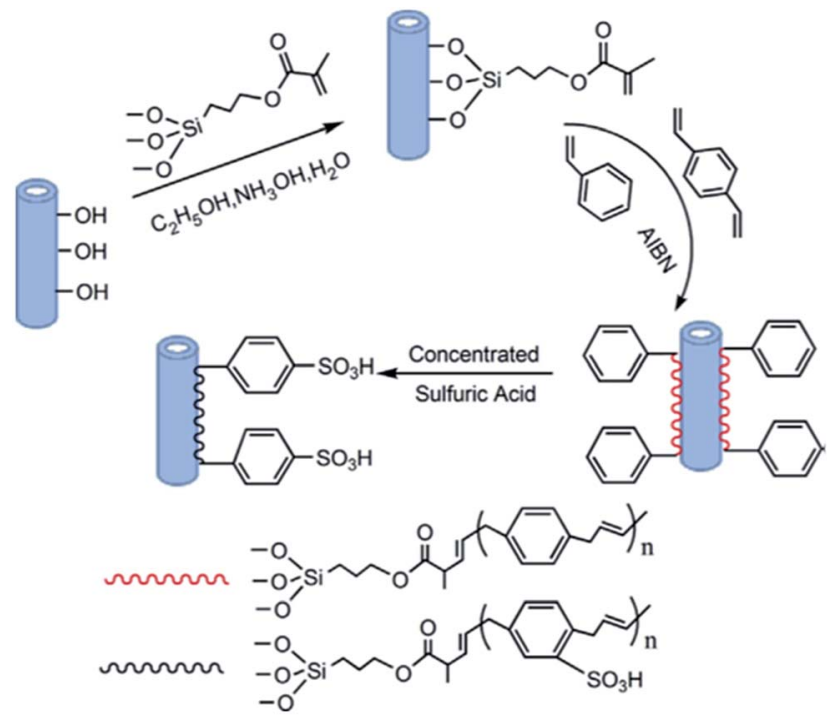

Fig. 6 Schematic illustration of the overall preparation process of HNTS- $\mathrm{SO}_{3} \mathrm{H}^{193}$

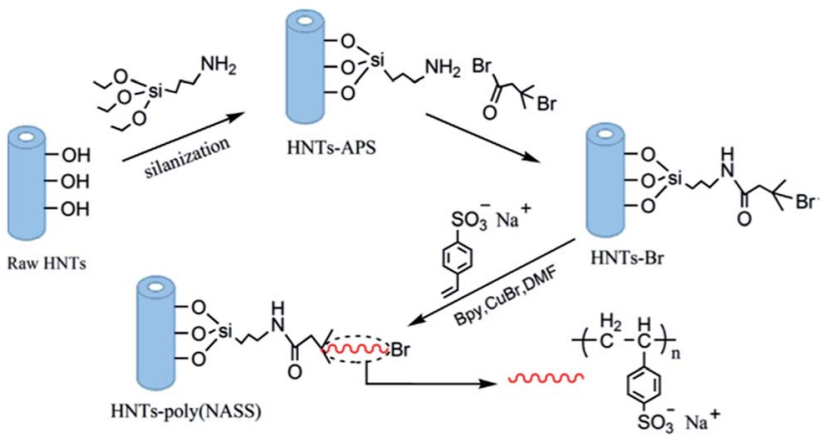

Fig. 7 Preparation process of sodium 4-styrene sulfonate grafted onto HNTs surface. ${ }^{201}$ membranes by increasing the hydrophilicity and surface charge of the membrane top layer, ${ }^{147-151,164,165}$ which will influence the permeability and reduce fouling. ${ }^{147-151,164-169}$ An increase in the surface charge will raise the Donnan exclusion effect and

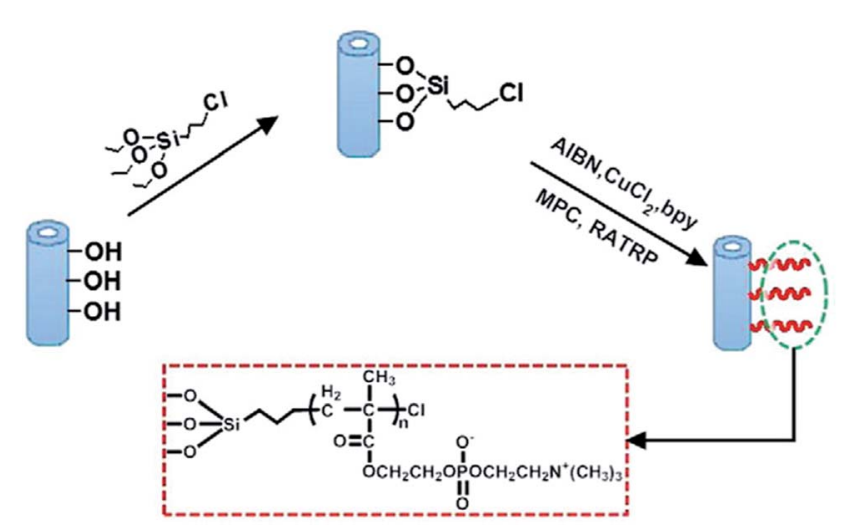

Fig. 8 Preparation process of HNTs-MPC via reverse atom transfer radical polymerization. ${ }^{202}$

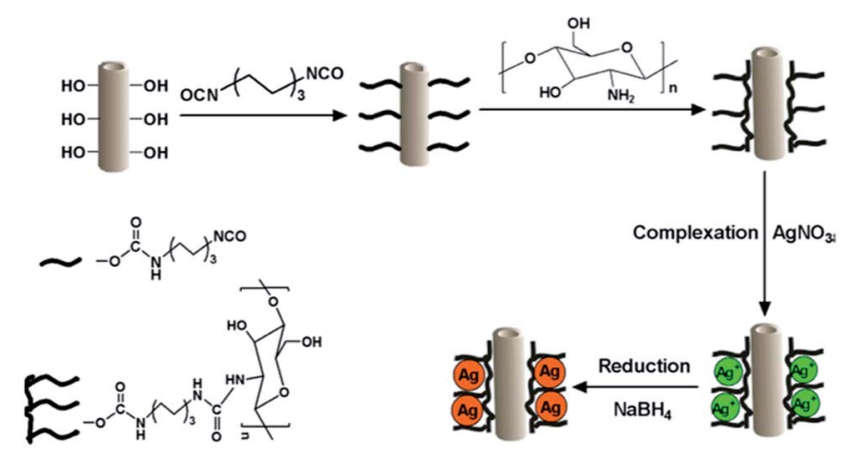

Fig. 9 Reaction principle for preparing HNTs-CS@Ag NPs. ${ }^{203}$

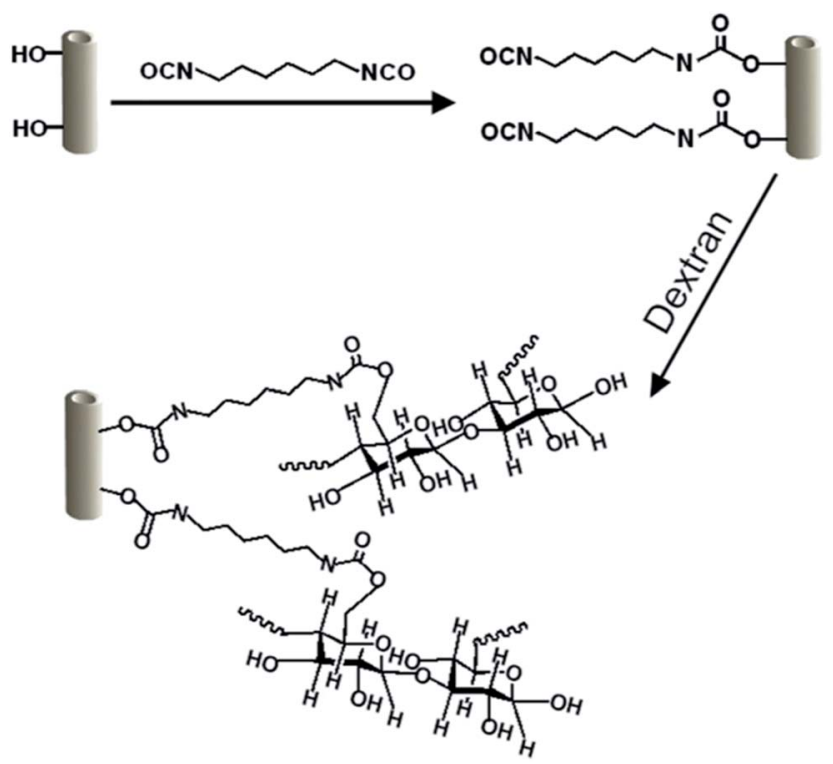

Fig. 10 Basic principles of the reactions of the modified HNTs. ${ }^{204}$ 
electrostatic interactions, which will result in an improved rejection of salt and an increase in hydrophilicity, which will provide better fouling resistance. ${ }^{\mathbf{1 7 0 , 1 7 1}}$ To date, several authors have shown the successful preparation of CNT-blended PES membranes. The summary of their results are presented in Table 5.

\section{Embedding halloysite nanotubes}

Halloysite nanotubes (HNTs) are a kind of naturally occurring aluminosilicate $\left(\mathrm{Al}_{2} \mathrm{Si}_{2} \mathrm{O}_{5}(\mathrm{OH})_{4} \cdot 2 \mathrm{H}_{2} \mathrm{O}\right)$ with a hollow nanotubular structure, ${ }^{\mathbf{1 9 1 , 1 9 2}}$ regular open-ending pores, as well as a great deal of hydroxyls on their surface ${ }^{193}$ HNTs can easily be dispersed in a polymer matrix, even at high loading due to their tubular shape, low density of hydroxyl functional groups, and well-crystallized structure. ${ }^{194-197}$ In contrast with other NPs, HNTs can be obtained easily and are much cheaper. ${ }^{\mathbf{1 9 8 , 1 9 9}}$ HNTs own a low charge density, which means they cannot affect the membrane potential when they are embedded into the polymer matrix. ${ }^{193}$ Recently, HNTs have been used as a new type of filler for PES to improve the properties and performance of the composites. For instance, ref. 200 synthesized a HNTs loaded with copper ions ( $\mathrm{Cu}^{2+}$-HNTs) by the chemical modification of HNTs, which were then incorporated in the PES matrix to produce $\mathrm{Cu}^{2+}$-HNTs/PES MMM, which significantly resulted in an improvement of membrane hydrophilicity, with WCA decreasing from $84.9^{\circ}$ to $69.8^{\circ}$ for $3 \mathrm{wt} \%$ of $\mathrm{Cu}^{2+}$-HNTs. Ref. ${ }^{193}$ presented a sulfonated halloysite nanotubes (HNTs-SO ${ }_{3} \mathrm{H}$ )/PES membrane. To prepare highly crosslinked $\mathrm{HNTs}-\mathrm{SO}_{3} \mathrm{H}$, styrene was grafted onto HNTs surface via distillation-precipitation polymerization and then sulfonated with concentrated sulfuric acid. Fig. 6 shows a schematic illustration of the overall preparation process of HNTs- $\mathrm{SO}_{3} \mathrm{H}$. The control PES membrane presented the highest contact angle of $83.5^{\circ}$, which was decreased to $58.3^{\circ}$ when $3 \mathrm{wt} \%$ HNTs-SO ${ }_{3} \mathrm{H}$ was introduced.

In another study by ref. 201, sodium 4-styrene sulfonate was grafted onto HNTs surfaces via surface-initiated atom transfer radical polymerization, as shown in Fig. 7, which was then introduced in the PES matrix to prepared negatively charged nanofiltration membranes. WCA was observed to decrease from $83.5^{\circ}$ to $56.6^{\circ}$ at $3 \mathrm{wt} \%$.

Ref. 202 reported a PES hybrid membrane containing HNTs grafted with 2-methacryloyloxyethyl phosphorylcholine (MPC). Fig. 8 presents the preparation process of HNTs-MPC via reverse

Table 6 Summaries of the applications of hydrophilic PES-organic membranes

\begin{tabular}{|c|c|c|c|c|}
\hline Additive & $\begin{array}{l}\text { Application } \\
\text { (operating pressure) }\end{array}$ & $\begin{array}{l}\text { Performance of neat membrane } \\
\left\{\mathrm{MR}\left(\mathrm{m}^{-1}\right) ; \mathrm{PWF}\left(\mathrm{L} \mathrm{m}^{-2} \mathrm{~h}^{-1}\right) ;\right. \\
\text { PF }\left(\mathrm{L} \mathrm{m}^{-2} \mathrm{~h}^{-1}\right) ; \mathrm{HP}\left(\mathrm{L} \mathrm{m}^{-2} \mathrm{~h}^{-1}\right) ; \\
R(\%) ; \text { FRR }(\%) ; \operatorname{RFR}(\%)\}\end{array}$ & $\begin{array}{l}\text { Performance of composite } \\
\text { membrane }\left\{\mathrm{MR}\left(\mathrm{m}^{-1}\right) ;\right. \\
\text { PWF }\left(\mathrm{L} \mathrm{m}^{-2} \mathrm{~h}^{-1}\right) ; \mathrm{PF}\left(\mathrm{L} \mathrm{m}^{-2} \mathrm{~h}^{-1}\right) \text {; } \\
\text { HP }\left(\mathrm{L} \mathrm{m}^{-2} \mathrm{~h}^{-1}\right) ; R(\%) ; \\
\text { FRR }(\%) ; \operatorname{RFR}(\%)\}\end{array}$ & Ref. \\
\hline PSA-PVP & Protein purification (4 bar) & PWF: 12.3; PF: 9.5; FRR: 76; BSA R: 95.9 & $\begin{array}{l}\text { PWF: 244.2; PF: } 57 \text {; } \\
\text { FRR: } 60.2 ; \text { BSA } R: 97.8\end{array}$ & 27 \\
\hline PA- 6 & Protein purification ( 4 bar) & PWF: 7.1; BSA $R:$ 92.4; FRR: N/A & PWF: 80.7; BSA $R:$ : 98.5; FRR: 64.2 & 26 \\
\hline PEG & Water treatment $(1$ bar $)$ & HP: $4.998 ;$ MR: $8.060 \times 10^{-11}$ & HP: 9.422; MR: $4.275 \times 10^{-11}$ & 22 \\
\hline PVP & Protein purification (4 bar) & PWF: 7.1; BSA $R:$ 92.4; FRR: (N/A) & PWF: 166.5; BSA $R$ : 95.6; FRR: 57 & 26 \\
\hline PVP & Protein purification ( 4 bar) & PWF: 12.3; PF: 9.5; FRR: 76; BSA $R: 95.9$ & $\begin{array}{l}\text { PWF: 277.4; PF: } 63.6 \\
\text { FRR: } 54.6 ; \text { BSA } R: 97.6\end{array}$ & 27 \\
\hline PEG-PVP & Water treatment ( 2 bar) & PWF: 2201.8 & PWF: 18899.1 & 23 \\
\hline PES- $g$-PDMAEMA & Protein purification ( 2 bar) & PWF: 18.76; $R: 99$ & PWF: $126.7 ; R: 96.4$ & 33 \\
\hline PEG & Protein purification (1 bar) & PWF: N/A; BSA $R:$ N/A & PWF: 76.7; BSA R: 99 & 236 \\
\hline PVP- $b$-PMMA- $b$-PVP & Protein purification ( 0.05 bar) & FRR: 50.6; PA: 19.3 & FRR: 96.6; PA: 10 & 39 \\
\hline PVP & Water treatment ( 1 bar $)$ & PWF: 64.34; $R: 96.03$ & PWF: $108.09 ; R: 88.07$ & 24 \\
\hline PES- $g$-PNIPAAm & Protein purification (2 bar) & PWF: 18.76; R: 99 & PWF: $110 ; R: 97.5$ & 33 \\
\hline PVP & Wastewater treatment ( 1 bar $)$ & PWF: $2.2 ;$ BSA $R: 88.9$ & PWF: 15.8; BSA R: 65 & 25 \\
\hline PES- $b$-PSBMA & Protein purification (1 bar) & PWF: 45.6; FRR: 49.3; BSA $R: 76$ & PWF: 115; FRR: 84.2; BSA $R: 80.7$ & 40 \\
\hline P31R1 & Wastewater treatment ( 1 bar $)$ & PWF: $2.2 ;$ BSA $R: 88.9$ & PWF: 116.5; BSA $R: 62.4$ & 25 \\
\hline F127- $b$-PDMAEMA & Protein purification (2 bar) & PA: 13.2 & PA: 34.3 & 34 \\
\hline T904 & Wastewater treatment ( 1 bar $)$ & PWF: 2.2 ; BSA $R: 88.9$ & PWF: 62; BSA $R: 69.2$ & 25 \\
\hline PVP & Protein purification (2.5 bar) & $\begin{array}{l}\text { PWF: 67.6; } \mathrm{PEG}_{35 \mathrm{k}} R: 99.2 ; \\
\text { PEG }_{20 \mathrm{k}} R: 98.1 ; \mathrm{PEG}_{10 \mathrm{k}} R: 97.9 ; \\
\mathrm{PEG}_{4 \mathrm{k}} R: 93.5\end{array}$ & $\begin{array}{l}\text { PWF: } 134.8 ; \mathrm{PEG}_{35 \mathrm{k}} R: 97.9 ; \\
\mathrm{PEG}_{20 \mathrm{k}} R: 97.9 ; \mathrm{PEG}_{10 \mathrm{k}} R: 97.3 ; \\
\mathrm{PEG}_{4 \mathrm{k}} R: 94.8\end{array}$ & 237 \\
\hline PSf- $g$-POEM & Protein purification (1.5 bar) & PA: 44.2; BSA R: 74; FRR: 51.7 & PA: 22.3 ; BSA $R: 0$; FRR: 80.8 & 35 \\
\hline PVP & Wastewater treatment ( 5 bar) & $\begin{array}{l}\text { PWF: } 108.21 ; \text { FRR: } 38.8 \\
\text { COD } R: 79.4 ; \text { TDS } R: 71.3\end{array}$ & $\begin{array}{l}\text { PWF: 59.2; FRR: } 59 \text {; } \\
\text { COD } R: 84.4 ; \text { TDS } R: 78.5\end{array}$ & 28 \\
\hline PVP & Water treatment ( 2 bar) & PWF: N/A; PF: N/A; FRR: N/A; HA R: N/A & $\begin{array}{l}\text { PWF: } 2439 ; \text { PF: } 266.5 ; \\
\text { FRR: } 98.5 ; \text { HA } R: 89.4\end{array}$ & 238 \\
\hline MF- $g$-PEG $6 \mathrm{k}$ & Water treatment ( 1 bar) & PWF: 60.7; FRR: 70.8 & PWF: 164.7; FRR: 91.6 & 37 \\
\hline PVP & Water treatment $(0.2-0.3 \mathrm{bar})$ & PWF: 128.26 & PWF: 376.8 & 239 \\
\hline PMAAn-F127-PMAA & Protein purification (1 bar) & PWF: 180.8; BSA $R: 96.75$ & PWF: 238.6; BSA $R: 85.5$ & 38 \\
\hline NPhthCs & Water treatment (3-6 bar) & BSA flux: 17.6; HP: 7.1; BSA R: 90 & BSA flux: 55.2; HP: 26.8 ; BSA $R: 86$ & 29 \\
\hline
\end{tabular}


Table 7 Summaries of the applications of hydrophilic PES-inorganic membranes

\begin{tabular}{|c|c|c|c|c|}
\hline Additives & $\begin{array}{l}\text { Applications } \\
\text { (operating pressure) }\end{array}$ & $\begin{array}{l}\text { Performance of neat } \\
\text { membrane }\left\{\text { PWF }\left(\mathrm{L} \mathrm{m}^{-2} \mathrm{~h}^{-1}\right) \text {; }\right. \\
\text { PF }\left(\mathrm{L} \mathrm{m}^{-2} \mathrm{~h}^{-1}\right) ; R(\%) ; \text { FRR }(\%) \text {; } \\
\text { RFR }(\%)\}\end{array}$ & $\begin{array}{l}\text { Performance of composite } \\
\text { membrane }\left\{\mathrm{PWF}\left(\mathrm{L} \mathrm{m}^{-2} \mathrm{~h}^{-1}\right) \text {; }\right. \\
\text { PF }\left(\mathrm{L} \mathrm{m}^{-2} \mathrm{~h}^{-1}\right) ; R(\%) ; \text { FRR }(\%) \text {; } \\
\text { RFR }(\%)\}\end{array}$ & Ref. \\
\hline CNTs & Desalination (4 bar) & PWF: $24.25 ; \mathrm{Na}_{2} \mathrm{SO}_{4} R: 24.7$ & PWF: 52.86; $\mathrm{Na}_{2} \mathrm{SO}_{4} R: 71.71$ & 172 \\
\hline $\mathrm{Fe}_{3} \mathrm{O}_{4}$ & Water treatment ( 4 bar) & $\mathrm{Cu}^{+} R: 19.5 ;$ PWF: 8.8 & $\mathrm{Cu}^{+} R: 34.4 ;$ PWF: 16.8 & 92 \\
\hline CNTs & Desalination (4 bar) & PWF: $24.25 ; \mathrm{Na}_{2} \mathrm{SO}_{4} R: 24.7$ & PWF: $38.91 ; \mathrm{Na}_{2} \mathrm{SO}_{4} R: 87.25$ & 172 \\
\hline $\mathrm{TiO}_{2}$ & Water treatment (10 bar) & PWF: 1.7 & PWF: 8.2 & 66 \\
\hline $\mathrm{Fe}_{3} \mathrm{O}_{4}-\mathrm{SiO}_{2}$ & Water treatment (4 bar) & $\mathrm{Cu}^{+} R: 19.5 ;$ PWF: 8.8 & $\mathrm{Cu}^{+} R:$ 40.7; PWF: 32.6 & 92 \\
\hline GO & Protein purification ( 1 bar) & PWF: 2; FRR: 26; BSA $R: 88.6$ & PWF: 37; FRR: 58; BSA R: 95.3 & 117 \\
\hline $\mathrm{TiO}_{2}$ & Wastewater treatment ( 6 bar) & PWF: 21; DR23 R: 97 & PWF: 33.4; DR23 R: 94.9 & 67 \\
\hline SWCNT & Wastewater treatment ( 2 bar) & $\begin{array}{l}\text { FRR: 93.7; BPA } R: 45.7 ; \text { NPH } R \text { : } \\
62.95 \text {; BPA flux: } 30.5 ; \text { NPH flux: } \\
42\end{array}$ & $\begin{array}{l}\text { FRR: 96.8; BPA } R: 45.2 ; \mathrm{NPH} R \text { : } \\
59.2 \text {; BPA flux: } 30.2 ; \mathrm{NPH} \text { flux: } \\
39.5\end{array}$ & 173 \\
\hline $\mathrm{PES} / \mathrm{Fe}_{3} \mathrm{O}_{4}-\mathrm{SiO}_{2}$-amine & Water treatment (4 bar) & $\mathrm{Cu}^{+} R: 19.5 ;$ PWF: 8.8 & $\mathrm{Cu}^{+} R: 79.7 ;$ PWF: 14.3 & 92 \\
\hline $\mathrm{TiO}_{2}$ & Wastewater treatment ( 5 bar) & $\begin{array}{l}\text { PWF: 23; FRR: 75.2; RG19 } R \text { : } \\
\text { 92.9; RB21 R: 88.9; DY12 R: } \\
61.4\end{array}$ & $\begin{array}{l}\text { PWF: 32.6; FRR: 87.4; RG19 R: } \\
\text { 99; RB21 R: 73.2; DY12 R: } 91.1\end{array}$ & 68 \\
\hline MWCNT & Water treatment ( 4 bar) & FRR: 44; PWF: 9 & FRR: 95; PWF: 23 & 174 \\
\hline $\mathrm{Fe}_{3} \mathrm{O}_{4}-\mathrm{SiO}_{2}-\mathrm{Met}$ & Water treatment ( 4 bar) & $\mathrm{Cu}^{+} R: 19.5 ;$ PWF: 8.8 & $\mathrm{Cu}^{+} R: 92.3 ;$ PWF: 27.8 & 92 \\
\hline $\begin{array}{l}\text { Mechanically modified } \\
\mathrm{TiO}_{2}\end{array}$ & Water treatment ( 1 bar) & FRR: 83.33; PWF: 17.6 & FRR: 51.85; PWF: 39.8 & 71 \\
\hline FeN & Water treatment ( 1 bar) & $\begin{array}{l}\text { PWF: } 6.1 ; \mathrm{Cu}+R: 95 ; \mathrm{Zn}^{2+} R: \\
95 ; \mathrm{Cu}^{+} \text {flux: } 4.7 ; \mathrm{Zn}^{2+} \text { flux: } 5.2\end{array}$ & $\begin{array}{l}\text { PWF: } 24 ; \mathrm{Cu}+R: 89.7 ; \mathrm{Zn}^{2+} R: \\
87 ; \mathrm{Cu}^{+} \text {flux: } 12.9 ; \mathrm{Zn}^{2+} \text { flux: } \\
13.6\end{array}$ & 91 \\
\hline MWCNT & Water treatment ( 4 bar) & FRR: 44; PWF: 9 & FRR: 67; PWF: 30.5 & 174 \\
\hline $\begin{array}{l}\text { Mechanically and } \\
\text { chemically modified } \mathrm{TiO}_{2}\end{array}$ & Water treatment ( 1 bar) & FRR: 83.33; PWF: 17.6 & FRR: 61.54; PWF: 54.9 & 71 \\
\hline GO-T904 & Protein purification (1 bar) & PWF: 2; FRR: 26; BSA $R: 89.3$ & PWF: 245; FRR: 62; BSA $R: 93.6$ & 117 \\
\hline A-PCC & Wastewater treatment (1.5 bar) & $\begin{array}{l}\text { PWF: } 102 ; \text { PF: } 49.87 \text {; FRR: } 61.8 \text {; } \\
\text { oil } R: 93.9\end{array}$ & $\begin{array}{l}\text { PWF: } 180 \text {; PF: } 102.15 \text {; FRR: } \\
\text { 86.4; oil } R \text { : } 99.8\end{array}$ & 235 \\
\hline $\mathrm{Fe}_{3} \mathrm{O}_{4}$ & Water treatment (1-10 bar) & $\begin{array}{l}\text { PWF: } 12.3 ; \mathrm{NaCl} R: 15.3 \\
\mathrm{MgSO}_{4} R: 16.16\end{array}$ & $\begin{array}{l}\text { PWF: } 86.2 ; \mathrm{NaCl} R: 68 ; \mathrm{MgSO}_{4} \\
R: 82\end{array}$ & 83 \\
\hline $\begin{array}{l}\text { Mechanically and } \\
\text { chemically modified } \mathrm{TiO}_{2}\end{array}$ & Water treatment ( 1 bar) & FRR: 60; PA: 33.5; PWF: 364.8 & FRR: 84; PA: 22.6; PWF: 462.3 & 69 \\
\hline MWCNT & Water treatment (4 bar) & FRR: 44; PWF: 9 & FRR: 76; PWF: 26 & 174 \\
\hline$n$-Ag & Protein purification ( 1 bar) & $\begin{array}{l}\text { PWF: } 25 \text {; FRR: } 53.5 ; \text { PF: } 42.7 \text {; } \\
\text { BSA } R: 97.4\end{array}$ & $\begin{array}{l}\text { PWF: 64; FRR: 79.4; PF: } 67.7 \text {; } \\
\text { BSA } R: 90.3\end{array}$ & 99 \\
\hline $\mathrm{TiO}_{2}$ & Water treatment ( 1 bar $)$ & FRR: 60; PA: 33.5; PWF: 364.8 & FRR: 57; PA: 37.5; PWF: 345.9 & 69 \\
\hline MWCNT & Water treatment ( 4 bar) & FRR: 44; PWF: 9 & FRR: 53; PWF: 23 & 174 \\
\hline AgNP & Water treatment (2-4 bar) & PWF: 365 & PWF: 327 & 97 \\
\hline $\mathrm{SiO}_{2} @ \mathrm{~N}$-Halamine & Water treatment ( 1 bar) & $\begin{array}{l}\text { PVA } R: \text { 96.2; PWF: 192.7; FRR: } \\
87\end{array}$ & $\begin{array}{l}\text { PVA } R: 94.8 ; \text { PWF: 384.9; FRR: } \\
96\end{array}$ & 77 \\
\hline $\begin{array}{l}\text { Amine-functionalized } \\
\text { MWCNT }\end{array}$ & Desalination ( 4 bar) & $\begin{array}{l}\text { PWF: } 13.6 \text {; } \mathrm{Na}_{2} \mathrm{SO}_{4} R: 52 \text {; FRR: } \\
\text { 68.6; PA: } 60.9\end{array}$ & $\begin{array}{l}\text { PWF: } 23.7 ; \mathrm{Na}_{2} \mathrm{SO}_{4} R: 65 \text {; FRR: } \\
\text { 88.1; PA: } 41\end{array}$ & 176 \\
\hline TMU-5 & Water treatment (3 bar) & PWF: 133.29; FRR: 24.47 & PWF: 182.02; FRR: 98.74 & 224 \\
\hline Mesostructured SBA-15 & Water treatment ( 3 bar) & PWF: 181.4 & PWF: 316.1 & 75 \\
\hline PCL modified CNT & Desalination (8 bar) & $\begin{array}{l}\text { PWF: 28; Cd ions } R: 8.7 \text {; FRR: } \\
\text { 13.3; BSA flux: } 4.3\end{array}$ & $\begin{array}{l}\text { PWF: 61; Cd ions } R: 27 \text {; FRR: } \\
\text { 11.1; BSA flux: } 6.4\end{array}$ & 177 \\
\hline $\begin{array}{l}\text { PES/mesostructured SBA- } \\
\text { 15/CES-15 }\end{array}$ & Water treatment ( 3 bar) & PWF: 181.4 & PWF: 351.7 & 75 \\
\hline GO & Wastewater treatment (4 bar) & PWF: 8.2; FRR: 35; dye $R: 90$ & PWF: 20.4; FRR: 90.5; dye $R: 96$ & 118 \\
\hline $\begin{array}{l}\text { Mesostructured SBA-15- } \\
\text { APTMS-15 }\end{array}$ & Water treatment (3 bar) & PWF: 181.4 & PWF: 356.8 & 75 \\
\hline ZIF-L & Water treatment (1 bar) & PWF: 215; FRR: 72 & PWF: 378; FRR: 82 & 225 \\
\hline F-MWCNTs & Protein purification ( 3 bar) & $\begin{array}{l}\text { PWF: 124; PF: 14.5; BSA } R \text { : } \\
\text { 86.5; FRR: } 27\end{array}$ & $\begin{array}{l}\text { PWF: } 184 \text {; PF: } 33.2 \text {; BSA } R: 81 \text {; } \\
\text { FRR: } 46\end{array}$ & 1 \\
\hline $\begin{array}{l}\text { Mesostructured SBA-15/ } \\
\text { AEAPTMS-15 }\end{array}$ & Water treatment ( 3 bar) & PWF: 181.4 & PWF: 595.8 & 75 \\
\hline Hydroxylated MWCNT & Water treatment ( 1 bar $)$ & PWF: 587.1 & PWF: 812.9 & 178 \\
\hline $\begin{array}{l}\text { Mesostructured SBA-15/ } \\
\text { CES-30 }\end{array}$ & Water treatment ( 3 bar $)$ & PWF: 181.4 & PWF: 463.6 & 75 \\
\hline Carboxylated MWCNT & Water treatment ( 1 bar) & PWF: 587.1 & PWF: 412.9 & 178 \\
\hline
\end{tabular}


Table 7 (Contd.)

\begin{tabular}{|c|c|c|c|c|}
\hline Additives & $\begin{array}{l}\text { Applications } \\
\text { (operating pressure) }\end{array}$ & $\begin{array}{l}\text { Performance of neat } \\
\text { membrane }\left\{\mathrm{PWF}\left(\mathrm{L} \mathrm{m}^{-2} \mathrm{~h}^{-1}\right) \text {; }\right. \\
\text { PF }\left(\mathrm{L} \mathrm{m}^{-2} \mathrm{~h}^{-1}\right) ; R(\%) ; \operatorname{FRR}(\%) \text {; } \\
\text { RFR }(\%)\}\end{array}$ & $\begin{array}{l}\text { Performance of composite } \\
\text { membrane }\left\{\mathrm{PWF}\left(\mathrm{L} \mathrm{m}^{-2} \mathrm{~h}^{-1}\right) ;\right. \\
\operatorname{PF}\left(\mathrm{L} \mathrm{m}^{-2} \mathrm{~h}^{-1}\right) ; R(\%) ; \operatorname{FRR}(\%) ; \\
\text { RFR }(\%)\}\end{array}$ & Ref. \\
\hline $\mathrm{Nano}_{-} \mathrm{SiO}_{2}$ & $\begin{array}{l}\text { Wastewater treatment (2-6 } \\
\text { bar) }\end{array}$ & $\begin{array}{l}\text { FRR: } 82.1 \text {; HA flux: } 59.2 \text {; HA } R \text { : } \\
\text { 94.1; MB flux: } 81.1 \text {; MB } R: 32.5\end{array}$ & $\begin{array}{l}\text { FRR: 86.2; HA flux: 77.4; HA } R: \\
\text { 94.7; MB flux: 92.9; MB } R: 42.2\end{array}$ & 74 \\
\hline GO-PAA & Wastewater treatment (4 bar) & $\begin{array}{l}\text { PWF: } 43 ; \text { PF: } 9.8 \text {; CR (SM): 44.1; } \\
\text { CR (SWE): } 39.7\end{array}$ & $\begin{array}{l}\text { PWF: 57; PF: 21.8; CR (SM): } \\
\text { 53.5; CR (SWE): } 48.8\end{array}$ & 119 \\
\hline $\mathrm{SiO}_{2}$ & Water treatment ( 4 bar) & $\begin{array}{l}\text { PWF: 249.37; BSA } R \text { : 91.9; FRR: } \\
80.6\end{array}$ & $\begin{array}{l}\text { PWF: 510.76; BSA R: 97.8; FRR: } \\
98\end{array}$ & 73 \\
\hline Oxidized MWCNT & Desalination (4 bar) & $\begin{array}{l}\text { PWF: } 5 ; \mathrm{Na}_{2} \mathrm{SO}_{4} R: 20 ; \text { FRR: } \\
29.7\end{array}$ & $\begin{array}{l}\text { PWF: 7.3; } \mathrm{Na}_{2} \mathrm{SO}_{4} R: 75 ; \mathrm{FRR:} \\
87.7\end{array}$ & 179 \\
\hline $\mathrm{ZnO}$ & Protein purification (1 bar) & $\begin{array}{l}\text { PWF: 32.8; BSA R: 99.2; RFR: } \\
27.7\end{array}$ & $\begin{array}{l}\text { PWF: 116.6; BSA } R: 98.8 ; \text { RFR: } \\
7.8\end{array}$ & 82 \\
\hline CNT & Water treatment (4.1 bar) & TOC $R: 35.5 ; \mathrm{UVA}_{254} R: 20.2$ & TOC $R: 48.8 ; \mathrm{UVA}_{254} R: 41.8$ & 168 \\
\hline $\mathrm{ZnO}$ & Water treatment (1.5 bar) & $\begin{array}{l}\text { FRR: 97.01; PWF: } 30.42 ; \mathrm{HA} \\
\text { flux: 24.84; RFR: } 17.72\end{array}$ & $\begin{array}{l}\text { FRR: 91.1; PWF: 51.01; HA flux: } \\
\text { 44.64; RFR: } 12.27\end{array}$ & 81 \\
\hline CNT & Water treatment (3.5 bar) & $\begin{array}{l}\text { BSA } R: 95.8 \text {; OVA } R: 95.2 \text {; BSA } \\
\text { flux: } 3.2 \text {; OVA flux: } 2.1 \text {; FRR } \\
\text { (OVA*): } 31.7 \text {; FRR (BSA): } 40.8 \text {; } \\
\text { PWF: } 12\end{array}$ & $\begin{array}{l}\text { BSA } R: 98.2 \text {; OVA } R: 98.1 \text {; BSA } \\
\text { flux: } 35.1 \text {; OVA flux: } 26.1 \text {; FRR } \\
\left(\text { OVA }^{*}\right): 70.83 \text {; FRR (BSA): } 80 \text {; } \\
\text { PWF: } 70\end{array}$ & 180 \\
\hline $\mathrm{ZnO}$ & Water treatment (4 bar) & PWF: 31; FRR: 39.4 & PWF: 48; FRR: 68.9 & 84 \\
\hline UiO-66@GO & Water treatment (2.5 bar) & $\begin{array}{l}\text { PWF: } 3.8 ; \text { DR } R: 93.1 ; \text { MO } R: 85 \text {; } \\
\text { FRR: } 42.9\end{array}$ & $\begin{array}{l}\text { PWF: 15.8; DR } R: 98.4 ; \text { MO } R \text { : } \\
\text { 89.1; FRR: } 88.6\end{array}$ & 120 \\
\hline ZnO nanorod & Water treatment ( 4 bar) & PWF: 31; FRR: 39.4 & PWF: 50; FRR: 73.1 & 84 \\
\hline $\begin{array}{l}\text { Nano-hybrid f-MWCNT/ } \\
\mathrm{PVP}_{90}\end{array}$ & $\begin{array}{l}\text { Protein purification }(2.75-3.25 \\
\text { bar) }\end{array}$ & PWF: 7.6; PA: 16.9 & PWF: 71.7; PA: 7 & 181 \\
\hline CS-ZnO HNPS & Water treatment $(\mathrm{N} / \mathrm{A})$ & PWF: 1215.8 & PWF: 4135.8 & 85 \\
\hline SLS-CNT & Protein purification ( 1 bar) & $\begin{array}{l}\text { PWF: 141; BSA } R: \text { 97.9; PA: } \\
\text { 111.4; FRR: } 61.4\end{array}$ & $\begin{array}{l}\text { PWF: 595.6; BSA } R: \text { 95.8; PA: } \\
\text { 56.9; FRR: } 94.4\end{array}$ & 182 \\
\hline CZN & Protein purification (3 bar) & $\begin{array}{l}\text { BSA flux: 92.5; FRR: 44.6; PWF: } \\
514.1\end{array}$ & $\begin{array}{l}\text { BSA flux: } 117.7 ; \text { FRR: } 50.1 \text {; } \\
\text { PWF: } 678.5\end{array}$ & 86 \\
\hline $\mathrm{TiO}_{2}$ coated MWCNT & Desalination (5 bar) & $\begin{array}{l}\text { PWF: } 3.71 ; \text { FRR: } 53.1 ; \mathrm{Na}_{2} \mathrm{SO}_{4} \\
R: 69.5 ; \mathrm{NaCl} R: 36.1\end{array}$ & $\begin{array}{l}\text { PWF: } 4.35 \text {; FRR: } 83 ; \mathrm{Na}_{2} \mathrm{SO}_{4} R \text { : } \\
80.7 ; \mathrm{NaCl} R: 41.4\end{array}$ & 183 \\
\hline $\mathrm{ZrO}_{2}$ & $\begin{array}{l}\text { Wastewater treatment }(0.345- \\
3.1 \text { bar) }\end{array}$ & PWF: 878.3 & PWF: 1581 & 240 \\
\hline GO & Water treatment (at 2.5 bar) & $\begin{array}{l}\text { PWF: } 3.8 ; \text { DR } R: 93.1 ; \text { MO } R: 85 \text {; } \\
\text { FRR: } 42.9\end{array}$ & $\begin{array}{l}\text { PWF: 8.8; DR } R: 87.9 ; \text { MO } R \text { : } \\
\text { 81.4; FRR: } 84.3\end{array}$ & 120 \\
\hline $\mathrm{ZrO}_{2}$ & Protein purification (1 bar) & $\begin{array}{l}\text { BSA } R: 97.2 \text {; OVA } R: 94.6 \text {; PWF: } \\
8.2\end{array}$ & $\begin{array}{l}\text { BSA } R: 92.7 \text {; OVA } R: 91.2 ; \text { PWF: } \\
83.6\end{array}$ & 89 \\
\hline ZnO coated MWCNTs & Wastewater treatment (4 bar) & $\begin{array}{l}\text { Dye } R: 91 \text {; PWF: } 8.2 ; \text { PF: } 7.5 ; \\
\text { FRR: } 67.1\end{array}$ & $\begin{array}{l}\text { Dye } R: 96.1 \text {; PWF: } 16.7 \text {; PF: } \\
\text { 16.1; FRR: } 95.2\end{array}$ & 184 \\
\hline $\mathrm{Al}_{2} \mathrm{O}_{3}$ & Water treatment (4.5 bar) & PWF: 8.5; Cu $R: 28$ & PWF: 25.3; Cu $R: 55.9$ & 90 \\
\hline PAA grafted MWCNTs & Desalination (4 bar) & $\begin{array}{l}\mathrm{Na}_{2} \mathrm{SO}_{4} R: 48.4 ; \mathrm{NaCl} R: 0.56 \text {; } \\
\text { PWF: 8.9; FRR: } 52\end{array}$ & $\begin{array}{l}\mathrm{Na}_{2} \mathrm{SO}_{4} R: 65.5 ; \mathrm{NaCl} R: 19.1 ; \\
\text { PWF: 29.3; FRR: } 69\end{array}$ & 185 \\
\hline Alumina & Protein purification (2 bar) & PWF: 182.2; BSA $R: 98.8$ & PWF: 209; BSA $R: 96.7$ & 70 \\
\hline rGO-TiO ${ }_{2}$ & Wastewater treatment (5 bar) & $\begin{array}{l}\text { PWF: 23; FRR: 75.2; RG19 } R \text { : } \\
\text { 92.9; DY12 R: 88.9; RB21 } R: \\
61.4\end{array}$ & $\begin{array}{l}\text { PWF: 43.3; FRR: } 96.8 \text {; RG19 } R \text { : } \\
99.2 \text {; DY12 R: 95.2; RB21 } R: \\
81.4\end{array}$ & 68 \\
\hline $\mathrm{ZrO}_{2}$ & Protein purification ( 2 bar) & PWF: 182.2; BSA $R: 98.8$ & PWF: 190.1; BSA $R: 95.2$ & 70 \\
\hline Ag coated MWCNTs & Water treatment ( 4 bar) & PWF: 554 & PWF: 556 & 186 \\
\hline $\mathrm{TiO}_{2}$ & Protein purification ( 2 bar) & PWF: 182.2; BSA $R: 98.8$ & PWF: 198.6; BSA R: 95.5 & 70 \\
\hline MWCNTs-PANI & Water treatment ( 1 bar) & HA $R: 18.4 ;$ PWF: 265.4 & HA R: 62.9; PWF: 1498.1 & 187 \\
\hline $\mathrm{Al}_{2} \mathrm{O}_{3}$ & $\begin{array}{l}\text { Water treatment }(0.69-1.03 \\
\text { bar) }\end{array}$ & PWF: 866.5 & PWF: 1268 & 241,242 \\
\hline $\mathrm{HMO}(0.75)-\mathrm{TiO}_{2}(0.25)$ & Wastewater treatment ( 1 bar $)$ & $\begin{array}{l}\text { PWF: } 23.71 \text {; oil } R: 98.16 \text {; FRR: } \\
45.9\end{array}$ & $\begin{array}{l}\text { PWF: 28.48; oil } R: 98.57 \text {; FRR: } \\
91.5\end{array}$ & 243 \\
\hline GO & Wastewater treatment ( 5 bar) & $\begin{array}{l}\text { PWF: 23; FRR: 75.2; RG19 } R: \\
\text { 92.9; DY12 R: 88.9; RB21 } R: \\
61.4\end{array}$ & $\begin{array}{l}\text { PWF: 35.9; FRR: 90.7; RG19 R: } \\
\text { 98.7; DY12 R: 89.6; RB21 R: } \\
69.4\end{array}$ & 68 \\
\hline $\mathrm{Cu} 2+-\mathrm{HNTs}$ & Protein purification ( 1 bar) & $\begin{array}{l}\text { PF: } 73.1 ; \mathrm{PEG}_{10 \mathrm{k}} R: 84.3 \\
\mathrm{PEG}_{20 \mathrm{k}} R: 95.2\end{array}$ & $\begin{array}{l}\text { PF: } 120 ; \mathrm{PEG}_{10 \mathrm{k}} R: 73.9 ; \mathrm{PEG}_{20 \mathrm{k}} \\
R: 93\end{array}$ & 200 \\
\hline Magnetic-treated $\mathrm{Fe}_{3} \mathrm{O}_{4}$ & Water treatment (4 bar) & PWF: 36; FRR: 52 & PWF: 65; FRR: 77.7 & 93 \\
\hline
\end{tabular}




\begin{tabular}{|c|c|c|c|c|}
\hline Additives & $\begin{array}{l}\text { Applications } \\
\text { (operating pressure) }\end{array}$ & $\begin{array}{l}\text { Performance of neat } \\
\text { membrane }\left\{\mathrm{PWF}\left(\mathrm{L} \mathrm{m}^{-2} \mathrm{~h}^{-1}\right) \text {; }\right. \\
\text { PF }\left(\mathrm{L} \mathrm{m}^{-2} \mathrm{~h}^{-1}\right) ; R(\%) ; \operatorname{FRR}(\%) ; \\
\text { RFR }(\%)\}\end{array}$ & $\begin{array}{l}\text { Performance of composite } \\
\text { membrane }\left\{\mathrm{PWF}\left(\mathrm{L} \mathrm{m}^{-2} \mathrm{~h}^{-1}\right) \text {; }\right. \\
\text { PF }\left(\mathrm{L} \mathrm{m}^{-2} \mathrm{~h}^{-1}\right) ; R(\%) ; \mathrm{FRR}(\%) \\
\text { RFR }(\%)\}\end{array}$ & Ref. \\
\hline $\mathrm{Fe}-\mathrm{Ag} / \mathrm{f}-\mathrm{MWCNT}$ & Water treatment ( 4 bar) & $\begin{array}{l}\text { PWF: } 26.5 ; \mathrm{Cr}^{6+} \text { ions } R: 9.34 \text {; } \\
\text { FRR: } 64\end{array}$ & $\begin{array}{l}\text { PWF: } 36.9 ; \mathrm{Cr}^{6+} \text { ions } R: 94.8 \text {; } \\
\text { FRR: } 94.98\end{array}$ & 188 \\
\hline $\mathrm{HMO}(0.25)-\mathrm{TiO}_{2}(0.75)$ & Wastewater treatment (1 bar) & PWF: 23.71; $R:$ 98.16; FRR: 45.9 & PWF: 27.33; R: 97.17; FRR: 63.6 & 243 \\
\hline HMO & Protein purification (1.5 bar) & $\begin{array}{l}\text { PWF: } 39.4 ; \text { BSA } R: 57 \text {; pepsin } R \text { : } \\
50 ; \text { trypsin } R: 39 ; \text { FRR: } 53.7 \text {; } \\
\text { BSA flux: } 17.3\end{array}$ & $\begin{array}{l}\text { PWF: } 499.2 ; \text { BSA } R: 85 ; \text { pepsin } \\
R: 70 ; \text { trypsin } R: 66 ; \text { FRR: } 96.2 \text {; } \\
\text { BSA flux: } 158.4\end{array}$ & 232 \\
\hline $\mathrm{SiO}_{2}$ & Wastewater treatment (1.5 bar) & $\begin{array}{l}\text { PWF: N/A; PF: N/A; oil R: N/A; } \\
\text { FRR: N/A }\end{array}$ & $\begin{array}{l}\text { PWF: 117; PF: 76.67; oil } R \text { : } \\
\text { 98.57; FRR: } 81\end{array}$ & 244 \\
\hline Sulfonated HNT & $\begin{array}{l}\text { Desalination and wastewater } \\
\text { treatment ( } 4 \text { bar) }\end{array}$ & $\begin{array}{l}\text { PWF: } 29.3 ; \mathrm{NaCl} R: 16.5 ; \mathrm{MgCl}_{2} \\
R: 22.8 ; \mathrm{Na}_{2} \mathrm{SO}_{4} R: 17.2 ; \mathrm{MgSO}_{4} \\
R: 17.5 ; \mathrm{RR} 49 R: 93.6 ; \mathrm{RB} 5 R: \\
94.9\end{array}$ & $\begin{array}{l}\text { PWF: } 40.3 ; \mathrm{NaCl} R: 1.9 ; \mathrm{MgCl}_{2} \\
R: 7.4 ; \mathrm{Na}_{2} \mathrm{SO}_{4} R: 16.4 ; \mathrm{MgSO}_{4} \\
R: 13.6 ; \mathrm{RR} 49 R: 90.4 ; \mathrm{RB} 5 R: 94\end{array}$ & 193 \\
\hline $\begin{array}{l}\text { Magnetic-treated PANI/ } \\
\mathrm{Fe}_{3} \mathrm{O}_{4}\end{array}$ & Water treatment ( 4 bar) & PWF: 36; FRR: 52 & PWF: 52; FRR: 80 & 93 \\
\hline GO-ZnO & Wastewater treatment ( 5 bar) & PWF: 1.5 ; salt $R: 17$ & PWF: 13.5 ; salt $R: 28$ & 121 \\
\hline Magnetic-treated MWCNT & Water treatment (4 bar) & PWF: 36; FRR: 52 & PWF: 29; FRR: 64.6 & 93 \\
\hline TETA-MWCNT & Desalination (10 bar) & $\begin{array}{l}\text { PWF: } 36.27 ; \mathrm{NaCl} R: 18.58 ; \\
\mathrm{Na}_{2} \mathrm{SO}_{4} R: 72.65 ; \mathrm{MgCl}_{2} R: \\
47.23 ; \mathrm{MgSO}_{4} R: 62.08 ; \mathrm{FRR}: \\
72.9\end{array}$ & $\begin{array}{l}\text { PWF: } 84.35 ; \mathrm{NaCl} R: 27.02 ; \\
\mathrm{Na}_{2} \mathrm{SO}_{4} R: 32.56 ; \mathrm{MgCl}_{2} R: \\
92.73 ; \mathrm{MgSO}_{4} R: 55.36 ; \mathrm{FRR}: \\
93.1\end{array}$ & 189 \\
\hline $\begin{array}{l}\text { Chitosan nano- } \\
\text { biopolymers }\end{array}$ & Water treatment ( 4 bar) & PWF: 13 & PWF: 22 & 234 \\
\hline $\mathrm{Fe}_{3} \mathrm{O}_{4}$ & Water treatment (4 bar) & PWF: 36; FRR: 52 & PWF: 33; FRR: 68 & 93 \\
\hline $\begin{array}{l}\text { Hollow mesoporous } \mathrm{SiO}_{2} \\
\text { spheres }\end{array}$ & Protein purification ( 1 bar) & PWF: 38; BSA R: 93.2; FRR: 62.2 & $\begin{array}{l}\text { PWF: 195.7; BSA } R: \text { 92.6; FRR: } \\
82.4\end{array}$ & 76 \\
\hline HPEI-GO & Protein purification (1 bar) & $\begin{array}{l}\text { FRR: 86.6; PWF: 204.5; PA: } \\
61.11\end{array}$ & $\begin{array}{l}\text { FRR: 92.1; PWF: 206.9; PA: } \\
25.89\end{array}$ & 114 \\
\hline HNTs-poly(NASS) & Desalination (4 bar) & $\begin{array}{l}\text { PWF: 29.4; RR49 R: 93.7; RB5 } \\
R: 95.2 ; \mathrm{NaCl} R: 83.5 ; \mathrm{MgCl}_{2} R: \\
77 ; \mathrm{Na}_{2} \mathrm{SO}_{4} R: 82.8 ; \mathrm{MgSO}_{4} R: \\
82.5\end{array}$ & $\begin{array}{l}\text { PWF: 97.5; RR49 R: 90.5; RB5 } \\
R: 91.7 ; \mathrm{NaCl} R: 97.2 ; \mathrm{MgCl}_{2} R: \\
96.5 ; \mathrm{Na}_{2} \mathrm{SO}_{4} R: 90 ; \mathrm{MgSO}_{4} R: \\
90.9\end{array}$ & 201 \\
\hline HNTs-CS@Ag & Protein purification ( 1 bar) & $\mathrm{PEG}_{20 \mathrm{k}} R: 94 ; \mathrm{PWF}: 112.11$ & $\mathrm{PEG}_{20 \mathrm{k}} R: 72.8 ;$ PWF: 375.8 & 203 \\
\hline $\mathrm{PANI} / \mathrm{Fe}_{3} \mathrm{O}_{4}$ & Protein purification ( 4 bar) & PWF: 36; FRR: 52 & PWF: 33; FRR: 68 & 93 \\
\hline MCNs & Protein purification ( 1 bar) & $\begin{array}{l}\text { PWF: 218.9; PF: } 37.8 \text {; FRR: } \\
\text { 64.9: PA: } 40.3 \text { : BSA } R: 99.9\end{array}$ & $\begin{array}{l}\text { PWF: } 257.8 \text {; PF: } 30.4 \text {; FRR: } \\
\text { 60.9: PA: 7.8: BSA } R: 99.9\end{array}$ & 233 \\
\hline HNTs-dextran & Protein purification ( 1 bar) & $\begin{array}{l}\text { PWF: 80.3; FRR: 86; } \mathrm{PEG}_{20 \mathrm{k}} R \text { : } \\
\text { 93.2; } \mathrm{PVA}_{30-70 \mathrm{k}} R: 96.9\end{array}$ & $\begin{array}{l}\text { PWF: 224.5; FRR: 96; } \mathrm{PEG}_{20 \mathrm{k}} R: \\
\text { 76.1; } \mathrm{PVA}_{30-70 \mathrm{k}} R: 100\end{array}$ & 204 \\
\hline f-MWCNTs & Wastewater treatment ( 4.1 bar) & PWF: $24.28 ;$ PF: 4.4 & PWF: 53.91; PF: 7.4 & 190 \\
\hline $\mathrm{Fe}_{3} \mathrm{O}_{4}$-MWCNT & Water treatment ( 4 bar) & PWF: 36; FRR: 52 & PWF: 45; FRR: 76.6 & 93 \\
\hline HNTs-MPC & Protein purification ( 1 bar) & $\begin{array}{l}\text { FRR: } 85.2 \text {; PWF: } 110.06 \\
\text { PEG }_{20 \mathrm{k}} R: 91.8 ; \text { PA: } 63.6\end{array}$ & $\begin{array}{l}\text { FRR: 93.1; PWF: } 224.39 \\
\text { PEG }_{20 \mathrm{k}} R: 83.6 ; \text { PA: } 8.3\end{array}$ & 202 \\
\hline CNC & Protein purification (2.7 bar) & PWF: 93.4; BSA $R$ : 93; FRR: 51 & PWF: 195; BSA $R:$ 96; FRR: 76.2 & 20 \\
\hline $\mathrm{SiO}_{2}$ & Wastewater treatment ( 1.5 bar) & $\begin{array}{l}\text { PWF: 87.347; PF: 60.112; oil } R \text { : } \\
\text { 95.77; FRR: 71.17; RFR: } 31.18\end{array}$ & $\begin{array}{l}\text { PWF: 102.43; PF: 90.937; oil } R \text { : } \\
\text { 99.98; FRR: 93.33; RFR: } 11.22\end{array}$ & 175 \\
\hline
\end{tabular}

atom transfer radical polymerization. The contact angle of the membrane decreased with the addition of HNTs-MPC. The WCA value was reduced from $88.4^{\circ}$ to $66.1^{\circ}$ at $3 \mathrm{wt} \%$.

Ref. 203 introduced HNTs-chitosan-Ag nanoparticles (HNTsCS@Ag) into the PES matrix. Prior to blending, the HNTsCS@Ag were synthesized by chemically modifying HNTs with chitosan, and then mixing with silver nitrate for complexing the silver ions, and finally the silver NPs were formed using sodium tetrahydroborate as a reducing agent. Fig. 9 presents the reaction principle for preparing the HNTs-CS@Ag NPs. The hybrid membranes were shown to be more hydrophilic, with the optimum membrane displaying the lowest contact angle of $55^{\circ}$ when the content of HNTs-CS@Ag amounted to $3 \mathrm{wt} \%$.

Ref. 204 presented polyethersulfone (PES) ultrafiltration membrane by incorporating dextran grafted HNTs (HNTsdextran). Fig. 10 presents the basic reactions of the modified HNTs. The results indicated that the surface hydrophilicity of the membranes was significantly improved after adding HNTsdextran. The WCA of the pristine PES membrane amounted to $90.8^{\circ}$, while the WCA of the hybrid membrane with the modified HNTs-dextran content of $3 \%$ was $58.3^{\circ}$. 


\section{Embedding metal-organic frameworks}

Metal-organic frameworks (MOFs) are organic-inorganic hybrid solids with infinite, uniform framework structures built from inorganic metal (or metal-containing cluster) nodes and organic linkers. ${ }^{\text {205-208 }}$ MOFs are zeolite-like structures but they do not have the limitations of zeolites in terms of the material's chemistry. MOFs are recently attracting a lot of attention as potential additive materials for MMMs, owing to their extraordinary porosity (as high as $50 \%$ of the crystal volume), high surface area (ranging from 1000 to $10000 \mathrm{~m}^{2} \mathrm{~g}^{-1}$ ), affinity for certain molecules, capability for functionalization, low density $\left(0.2-1 \mathrm{~g} \mathrm{~cm}^{-3}\right)$, tunable chemical composition, and flexible structure. ${ }^{209-212}$ MOFs have regular and highly harmonic pore structures and they play a very vital role in increasing the hydrophilic property of the membrane..$^{\text {213-223 }}$

To date, different types of MOFs, including zeolitic imidazolate framework (ZIF), ZIF-8, [Zn(oba)(4-bpdh) $\left.)_{0.5}\right] \cdot(\mathrm{DMF})_{1.5}$ (TMU-5), UiO-66, matériauxs de l'Institut Lavoisier, have been developed and introduced in the PES matrix to prepare a MMM. Their potentials have been well recognized both experimentally and computationally. ${ }^{\mathbf{1 2 0 2 2 4 - 2 3 0}}$ The emerging zirconium MOFs (Zr-MOFs) has exhibited exceptionally high chemical and thermal stability. ${ }^{231}$ Ref. 224 reported a novel hydrophilic PES/ TMU-5 UF membrane synthesized by blending with TMU-5. The growth of TMU-5 upon silk fiber was achieved by sequential dipping in alternating baths of aqueous $\mathrm{Zn}\left(\mathrm{NO}_{3}\right)_{2} \cdot 6 \mathrm{H}_{2} \mathrm{O}$ and DMF solution of 4-bpdh and $\left(\mathrm{H}_{2} \mathrm{Oba}\right)$ under an ultrasound bath. They found that upon the addition of $0.1 \mathrm{wt} \%$ NPs, the hydrophilicity was enhanced, with WCA declining from $67.2^{\circ}$ to $57.5^{\circ}$. In another study by ref. 225 , a two-dimensional zeolitic imidazolate framework with a leaf-shaped morphology (ZIF-L) was synthesized in zinc salt and 2-methylimidazole aqueous solution and then doped in the PES matrix to prepare the MMM. Upon the introduction of $0.5 \mathrm{wt} \%$ loading of NPs, the WCA declined slightly to $62.72^{\circ}$ as compared to the neat membrane of $67.72^{\circ}$.

\section{Other inorganic materials}

Ref. 232 synthesized hydrous manganese oxide (HMO) from the oxidation of manganous ions by permanganate and then impregnated them in the PES matrix which yielded a WCA of $27.2^{\circ}$ at $1.5 \mathrm{wt} \%$ of HMO as compared to the nascent membrane of $69.5^{\circ}$. Ref. 233 embedded mesoporous carbon nanoparticles (MCNs) to prepare a hydrophilic PES membrane, which resulted in a decreased WCA from $75^{\circ}$ to $36^{\circ}$ when the content of MCM was increased to $0.2 \mathrm{wt} \%$. In a study by ref. 20, cellulose nanocrystals (CNCs) were incorporated into PES membranes, which resulted in an improved hydrophilicity from $66.2^{\circ}$ to $51.3^{\circ}$ at $1 \mathrm{wt} \%$ of CNC. In another study by ref. 234 , chitosan nanobiopolymers (CS-NPs) were synthesized using tripoly phosphate and introduced in the PES matrix to prepare a nanobiopolymer composite membrane. The addition of $0.2 \mathrm{wt} \%$ nanopolymer caused a reduction of WCA from $73^{\circ}$ to $65^{\circ}$. Ref. 235 incorporated aragonite precipitated calcium carbonate (A-PCC) from magnesium rich carbonate rock into the PES matrix to prepare a PES composite membrane. They observed a reduction in WCA from $72.3^{\circ}$ to $62.5^{\circ}$ when the content of the A-PCC was $3 \mathrm{wt} \%$.

\section{Applications of the hydrophilic PES membrane}

With the increasing demand for functional hydrophilic membrane materials, a great deal of attention has been focused on the development of hydrophilic PES membranes. Due to their interaction with water, the use of a hydrophilic PES membrane has found use in various applications, such as desalination, water treatment, wastewater treatment, textile applications, and protein purifications. In fact, hydrophilic PES membrane modification via blending is a simple approach to overcoming the performance trade-off and minimizing membrane fouling. A significant number of works have shown that enhancing the hydrophilicity of the PES membrane will result in a reduction of membrane fouling as well as leading to performance improvement. Tables 6 and 7 show summaries of the applications of hydrophilic PES membranes.

\section{Conclusions and future prospects}

Seemingly the permanent hydrophilic modification of PES membranes can be achieved by blending with organic and/or inorganic materials. Furthermore, there is no denying the fact that the amount of data available today on the hydrophilic enhancement of PES membranes via blending is a stepping stone to upgrading PES membranes to new heights. Some of the conclusions drawn from this comprehensive review are listed as follows:

- To achieve an improved surface hydrophilicity and performance, many factors need to be considered in the overall process of composite membrane preparation, such as precise control over the functional groups, uniformity, and reproducibility. For instance, the functional groups on CNTs have the ability to be converted to membrane functional groups and can change the surface hydrophilicity and performance of the PES membrane. Therefore, more functional groups on CNTs are expected to reveal more significant changes in membrane hydrophilicity and performance. However, there is also a need for comprehensive investigation concerning the use and influence of multiple-modified SWCNTs and MWCNTs on PES NC membranes characteristics to verify the efficiency of PES modification of CNTs on the surface hydrophilization of PES membranes. Furthermore, the production costs of carbon nanotubes are quite high. Thus, further work should investigate and address the economic aspects so that their potentials for commercial scale can be realized.

- In the case of blending with inorganic materials, the interaction between PES and NPs is specific and the final membrane hydrophilicity and performance depends on such interaction. Therefore, the effectiveness of hydrophilicity will depend on the location of NPs in the membrane matrix because the location of NPs can change the diffusivity in the PES matrix. The surface energy and concentration are other important factors that can affect NPs dispersion and location, which could lead to NPs aggregation on the surface of the PES NC 
membrane. NPs aggregation will mean that the effectiveness of surface hydropilicity will be reduced during intended applications. To decrease the surface energy or improve the dispersion of NPs in the PES matrix, the surface modification of the NPs by grafting with a polymer can be an effective method.

- The use of a variety of functional and synthetic materials (i.e., lyotropic liquid crystals, aquaporins) will improve the hydrophilicity, enable the highest permeation rates, as well as keep the doors open for research and development in the field of multifunctional, high-performance, and antifouling PES membranes.

- Although, the combination of two or three additives can be more complex in terms of the environmental drawbacks and cost effectiveness, these could lead to multifunctional PES membranes that are of great interest for 'future hydrophilic PES membranes'. Comparison with the existing ones to determine their adaptability and sustainability for commercial purposes will be the next step.

- With a hydrophilic PES membrane, it should be mentioned that solute adsorption is reduced at the produced hydrophilic surfaces, but is never completely prevented. Therefore, it is expected that membrane surface hydrophilicity can be tuned for specific applications through the discussed methods, although they still need to be developed further in such a way that they allow even more and better environmentally friendly control over other modification methods.

- Finally, but also very important, is the processing ability and economic cost. Generally, the cost is a major concern in the commercialization of membrane technology. Some hydrophilic PES membranes might produce a better quality of permeate and solute removal but the operating costs may be higher. Thus, the cost associated with the synthesis and incorporation of these additives needs to be addressed at the earliest for their development from the laboratory to a commercial-applicable scale.

\section{Conflicts of interest}

We declare that there is no conflict of interest in this work.

\section{Symbols and abbreviations}

AA
AEAPTMS
$\mathrm{Ag}$
$\mathrm{Al}_{2} \mathrm{O}_{3}$, AgNP
$\mathrm{Al}_{2} \mathrm{O}_{3}$
A-PCC
APS
APTMS
ATRP
4-bpdh
BPA
BSA
CES
COD

Acrylic acid

[3-(2-Aminoethylamino)propyl]

trimethoxysilane

Silver

Silver nanoparticles

Aluminum oxide

Aragonite precipitated calcium carbonate

Ammonium peroxidisulfate

(3-Aminopropyl) trimethoxysilane

Atom transfer radical polymerization

2,5-Bis(4-pyridyl)-3,4-diaza-2,4-hexadiene

Bisphenol A

Bovine serum albumin

Carboxyethylsilanetriol sodium salt

Chemical oxygen demand

$\begin{array}{ll}\text { COOH } & \text { Carboxyl } \\ \text { CNC } & \text { Cellulose nanocrystals } \\ \text { CNTs } & \text { Carbon nanotubes } \\ \text { CR } & \text { Color rejection } \\ \text { CS } & \text { Chitosan } \\ \mathrm{Cu}^{2+} & \text { Copper ions } \\ \text { CZN } & \text { CuO/ZnO nanocomposite } \\ \text { DIW } & \text { Deionized water } \\ \text { DR } & \text { Direct red 80 } \\ \text { DY12 } & \text { Direct yellow 12 } \\ \text { EG } & \text { Ethylene glycol }\end{array}$

F127- $b$ -

PDMAEMA

F127-based amphiphilic block copolymers

containing poly $(\mathrm{N}, \mathrm{N}$-dimethylamino-2-ethyl

methacrylate) end blocks

Fe-NPs Iron oxide-based nanoparticles

FeN Iron nanoparticles

FRR (\%) Flux recovery ratio

GO Graphene oxide

$\mathrm{H}_{2} \mathrm{Oba} \quad 4,4^{\prime}$-Oxybisbenzoic acid

HA Humic acid

HMSS Hollow mesoporous silica sphere

HNTs Halloysite nanotubes

HNTs- $\mathrm{SO}_{3} \mathrm{H} \quad$ Sulfonated halloysite nanotubes

$\mathrm{HP}\left(\mathrm{L} \mathrm{m}^{-2} \mathrm{~h}^{-1}\right)$ Hydraulic permeability

HPEI Hyperbranched polyethylenimine

KPS Potassium persulfate

MB Methylene blue

Met Metformine

MF

$\mathrm{MgO}$

MO

Melamine formaldehyde

Manganese oxide

Methyl orange

Metal-organic frameworks

m- $-\mathrm{Fe}_{3} \mathrm{O}_{4} \quad$ Magnetic-treated $\mathrm{Fe}_{3} \mathrm{O}_{4}$

m-PANI $/ \mathrm{Fe}_{3} \mathrm{O}_{4} \quad$ Magnetic-treated polyaniline-coated $\mathrm{Fe}_{3} \mathrm{O}_{4}$

m-MWCNT/ Magnetic-treated $\mathrm{Fe}_{3} \mathrm{O}_{4}$ coated multi-walled

$\mathrm{Fe}_{3} \mathrm{O}_{4} \quad$ carbon nanotubes

MMM Mixed matrix membrane

MPC

$\operatorname{MR}\left(\mathrm{m}^{-1}\right)$

NC

$\mathrm{NPH}$

NPhthCs

NPs

NT

$\mathrm{OH}$

OVA

P31R1

PA

PA-6

PAA

$\mathrm{PANI} / \mathrm{Fe}_{3} \mathrm{O}_{4}$

PCA

PCL

PDMAEMA

2-Methacryloyloxyethyl phosphorylcholine

Membrane resistance

Nanocomposite

4-Nonylphenol

$N$-Phthaloyl-chitosan

Nanoparticles

Nanotubes

Hydroxyl

Ovalbumin

Linear pluronic 31R1

Protein adsorption

Polyamide

Polyacrylic acid

Polyaniline-coated $\mathrm{Fe}_{3} \mathrm{O}_{4}$

Polycitric acid

Polycaprolactone

Poly $(N, N$-dimethylamino-2-ethyl

methacrylate)

PEG Polyethylene glycol

PEO Polyethylene oxide

PES Polyethersulfone 
PES- $g$-PSBMA Polyethersulfone-block-poly(sulfobetaine methacrylate)

$\mathrm{PF}\left(\mathrm{L} \mathrm{m}^{-2} \mathrm{~h}^{-1}\right)$ Permeate flux

PMAA Poly(methacrylic acid)

PNIPAAm Poly ( $N$-isopropyl acrylamino)

PS- $b$-PAA Polystyrene-block-poly(acrylic acid)

PSA Polysulfide-amide

PSf- $g$-POEM polysulfone-graft-poly (ethylene glycol) methyl ether methacrylate

PVP Polyvinyl pyrrolidone

PWF $\left(\mathrm{L} \mathrm{m}^{-2} \quad\right.$ Pure water flux

$\mathrm{h}^{-1}$ )

R (\%)

RAFT

RB5

RB 21

RFR (\%)

RG 19

rGO

RR49

$\mathrm{SiO}_{2}$

SLS

SM

SWCNTS

SWE

T904Star-like

tetronic

TDS

TEOS

TETA

$\mathrm{TiO}_{2}$

TMU-5

WCA

WF $\left(\mathrm{L} \mathrm{m}^{-2} \mathrm{~h}^{-1}\right)$ Water flux

ZIF Zeolitic imidazolate framework

ZIF-L

Zeolitic imidazole framework with leaf-shaped morphology (ZIF-L)

$\mathrm{ZnO} \quad$ Zinc oxide

$\mathrm{ZrO}_{2} \quad$ Zirconium dioxide

\section{Acknowledgements}

The authors acknowledge the financial support provided by Universiti Sains Malaysia under the USM fellowship scheme, Fundamental Research Grant Scheme (FRGS) Ministry of Higher Education (MOHE) Malaysia (Grant no: 203.PJKIMIA.6071334 and 203.PJKIMIA.6071355), and Universiti Sains Malaysia (USM) RU Membrane Science and Technology Cluster.

\section{References}

1 A. Rahimpour, M. Jahanshahi, S. Khalili, A. Mollahosseini, A. Zirepour and B. Rajaeian, Desalination, 2012, 286, 99107.

2 Q. Shi, Y. Su, S. Zhu, C. Li, Y. Zhao and Z. Jiang, J. Membr. Sci., 2007, 303, 204-212.
3 H. Wang, L. Yang, X. Zhao, T. Yu and Q. Du, Chin. J. Chem. Eng., 2009, 17, 324-329.

4 C. Barth, M. C. Gonçalves, A. T. N. Pires, J. Roeder and B. A. Wolf, J. Membr. Sci., 2000, 169, 287-299.

5 N. Bolong, A. F. Ismail, M. R. Salim, D. Rana and T. Matsuura, J. Membr. Sci., 2009, 331, 40-49.

6 B. J. A. Tarboush, D. Rana, T. Matsuura, H. A. Arafat and R. M. Narbaitz, J. Membr. Sci., 2008, 325, 166-175.

7 M. Ulbricht, Polymer, 2006, 47, 2217-2262.

8 N. Hilal, O. O. Ogunbiyi, N. J. Miles and R. Nigmatullin, Sep. Sci. Technol., 2005, 40, 1957-2005.

9 A. G. Fane and C. J. D. Fell, Desalination, 1987, 62, 117-136.

10 A. Nabe, E. Staude and G. Belfort, J. Membr. Sci., 1997, 133, 57-72.

$11 \mathrm{~J}$. Mulder, Basic principles of membrane technology, Springer Science \& Business Media, 2012.

12 G. Kang and Y. Cao, Water Res., 2012, 46, 584-600.

13 T. Humplik, J. Lee, S. C. O'Hern, B. A. Fellma, M. A. Baig, S. F. Hassan, M. A. Atieh, F. Rahman, T. Laoui, R. Karnik and E. N. Wang, Nanotechnology, 2011, 22, 292001.

14 J. Gilron, S. Belfer, P. Väisänen and M. Nyström, Desalination, 2001, 140, 167-179.

15 H. Zou, Y. Jin, J. Yang, H. Dai, X. Yu and J. Xu, Sep. Purif. Technol., 2010, 72, 256-262.

16 V. Freger, J. Gilron and S. Belfer, J. Membr. Sci., 2002, 209, 283-292.

17 G. dong Kang and Y. ming Cao, J. Membr. Sci., 2014, 463, 145-165.

18 E. Yuliwati and A. F. Ismail, Desalination, 2011, 273, 226234.

19 C. Feng, B. Shi, G. Li and Y. Wu, J. Membr. Sci., 2004, 237, 15-24.

20 D. Zhang, A. Karkooti, L. Liu, M. Sadrzadeh, T. Thundat, Y. Liu and R. Narain, J. Membr. Sci., 2018, 549, 350-356.

21 D. Rana and T. Matsuura, Chem. Rev., 2010, 110, 2448-2471.

22 J. Garcia-Ivars, M. I. Alcaina-Miranda, M. I. Iborra-Clar, J. A. Mendoza-Roca and L. Pastor-Alcañiz, Sep. Purif. Technol., 2014, 128, 45-57.

23 T. Marino, E. Blasi, S. Tornaghi, E. Di Nicolò and A. Figoli, J. Membr. Sci., 2018, 549, 192-204.

24 B. Vatsha, J. C. Ngila and R. M. Moutloali, Phys. Chem. Earth, 2014, 67-69, 125-131.

25 A. Abdel-Karim, T. A. Gad-Allah, A. S. El-Kalliny, S. I. A. Ahmed, E. R. Souaya, M. I. Badawy and M. Ulbricht, Sep. Purif. Technol., 2017, 175, 36-46.

26 A. Shockravi, V. Vatanpour, Z. Najjar, S. Bahadori and A. Javadi, Microporous Mesoporous Mater., 2017, 246, 24-36.

27 A. Jalali, A. Shockravi, V. Vatanpour and M. Hajibeygi, Microporous Mesoporous Mater., 2016, 228, 1-13.

28 A. Sumisha, G. Arthanareeswaran, Y. Lukka Thuyavan, A. F. Ismail and S. Chakraborty, Ecotoxicol. Environ. Saf., 2015, 121, 174-179.

29 F. F. Ghiggi, L. D. Pollo, N. S. M. Cardozo and I. C. Tessaro, Eur. Polym. J., 2017, 92, 61-70.

30 F. Liu, N. A. Hashim, Y. Liu, M. R. M. Abed and K. Li, J. Membr. Sci., 2011, 375, 1-27.

31 A. Bushell, PhD thesis, University of Manchester, 2012. 
32 S. P. Nunes and A. Car, Ind. Eng. Chem. Res., 2013, 52, 9931003.

33 Z. Yi, L. Zhu, L. Cheng, B. Zhu and Y. Xu, Polymer, 2012, 53, 350-358.

34 Z. Yi, L. P. Zhu, Y. Y. Xu, X. L. Li, J. Z. Yu and B. K. Zhu, J. Membr. Sci., 2010, 364, 34-42.

35 Z. Yi, L. P. Zhu, Y. Y. Xu, Y. F. Zhao, X. T. Ma and B. K. Zhu, J. Membr. Sci., 2010, 365, 25-33.

36 T. Luo, S. Lin, R. Xie, X. J. Ju, Z. Liu, W. Wang, C. L. Mou, C. Zhao, Q. Chen and L. Y. Chu, J. Membr. Sci., 2014, 450, 162-173.

37 Y. Liu, Y. Su, X. Zhao, Y. Li, R. Zhang and Z. Jiang, J. Membr. Sci., 2015, 486, 195-206.

38 Y. Su, Y. Liu, X. Zhao, Y. Li and Z. Jiang, Chin. J. Chem. Eng., 2015, 23, 1283-1290.

39 F. Ran, S. Nie, W. Zhao, J. Li, B. Su, S. Sun and C. Zhao, Acta Biomater., 2011, 7, 3370-3381.

40 Y. F. Zhao, P. Bin Zhang, J. Sun, C. J. Liu, L. P. Zhu and Y. Y. Xu, J. Membr. Sci., 2016, 510, 306-313.

41 N. A. Hashim, F. Liu and K. Li, J. Membr. Sci., 2009, 345, 134-141.

42 J. K. Koh, Y. W. Kim, S. H. Ahn, B. R. Min and J. H. Kim, J. Polym. Sci., Part B: Polym. Phys., 2010, 48, 183-189.

43 J.-H. Li, M.-Z. Li, J. Miao, J.-B. Wang, X.-S. Shao and Q.-Q. Zhang, Appl. Surf. Sci., 2012, 258, 6398-6405.

44 Y. Sui, X. Gao, Z. Wang and C. Gao, J. Membr. Sci., 2012, 394-395, 107-119.

45 A. Bottino, Sep. Purif. Technol., 2001, 22-23, 269-275.

46 X. Cao, J. Ma, X. Shi and Z. Ren, Appl. Surf. Sci., 2006, 253, 2003-2010.

47 L. Yan, Y. S. Li and C. B. Xiang, Polymer, 2005, 46, 77017706.

48 A. Bottino, G. Capannelli and A. Comite, Desalination, 2002, 146, 35-40.

49 E. S. Džunuzović, J. V Džunuzović, A. D. Marinković, M. T. Marinović-Cincović, K. B. Jeremić and J. M. Nedeljković, Eur. Polym. J., 2012, 48, 1385-1393.

50 E. Džunuzović, K. Jeremić and J. M. Nedeljković, Eur. Polym. J., 2007, 43, 3719-3726.

51 W. Ji and S. K. Sikdar, Ind. Eng. Chem. Res., 1996, 35, 11241132.

52 J.-H. Li, Y.-Y. Xu, L.-P. Zhu, J.-H. Wang and C.-H. Du, J. Membr. Sci., 2009, 326, 659-666.

53 L.-H. Li, J.-C. Deng, H.-R. Deng, Z.-L. Liu and L. Xin, Carbohydr. Res., 2010, 345, 994-998.

54 K. Ebert, D. Fritsch, J. Koll and C. Tjahjawiguna, J. Membr. Sci., 2004, 233, 71-78.

55 A. Anžlovar, Z. Crnjak Orel and M. Žigon, Eur. Polym. J., 2010, 46, 1216-1224.

56 C. Calebrese, L. Hui, L. S. Schadler and J. K. Nelson, IEEE Trans. Dielectr. Electr. Insul., 2011, 18, 938-945.

57 Y. Hu, R. C. Smith, J. K. Nelson and L. S. Schadler, Annu. Rep. - Conf. Electr. Insul. Dielectr. Phenomena, CEIDP, 2006, pp. 31-34.

58 R. C. Smith, C. Liang, M. Landry, J. K. Nelson and L. S. Schadler, IEEE Trans. Dielectr. Electr. Insul., 2008, 15, 187-196.
59 H. Tong, S. Ouyang, Y. Bi, N. Umezawa, M. Oshikiri and J. Ye, Adv. Mater., 2012, 24, 229-251.

60 Y. Hou, L. Wu, X. Wang, Z. Ding, Z. Li and X. Fu, J. Catal., 2007, 250, 12-18.

61 N. Lu, H. T. Yu, Y. Su and Y. Wu, Sep. Purif. Technol., 2012, 90, 196-203.

62 L. Djafer, A. Ayral and A. Ouagued, Sep. Purif. Technol., 2010, 75, 198-203.

63 X. Zhu, C. Yuan, Y. Bao, J. Yang and Y. Wu, J. Mol. Catal. A: Chem., 2005, 229, 95-105.

64 A. Mills and S. Le Hunte, J. Photochem. Photobiol., A, 1997, 108, 1-35.

65 S. Q. Wang, Q. L. Liu and A. M. Zhu, Eur. Polym. J., 2011, 47, 1168-1175.

66 A. Sotto, A. Boromand, R. Zhang, P. Luis, J. M. Arsuaga, J. Kim and B. Van der Bruggen, J. Colloid Interface Sci., 2011, 363, 540-550.

67 M. Tilahun, J. Wang, J. Zhu and S. Velizarov, J. Membr. Sci., 2018, 550, 462-469.

68 M. Safarpour, V. Vatanpour and A. Khataee, Desalination, 2015, 393, 65-78.

69 A. Razmjou, J. Mansouri and V. Chen, J. Membr. Sci., 2011, 378, 73-84.

70 J. María Arsuaga, A. Sotto, G. del Rosario, A. Martínez, S. Molina, S. B. Teli and J. de Abajo, J. Membr. Sci., 2013, 428, 131-141.

71 A. Razmjou, A. Resosudarmo, R. L. Holmes, H. Li, J. Mansouri and V. Chen, Desalination, 2012, 287, 271-280.

72 D. Tang, R. Yuan and Y. Chai, Clin. Chem., 2007, 53, 13231329.

73 J. nan Shen, H. min Ruan, L. guang Wu and C. jie Gao, Chem. Eng. J., 2011, 168, 1272-1278.

74 J. Lin, W. Ye, K. Zhong, J. Shen, N. Jullok, A. Sotto and B. Van der Bruggen, Chem. Eng. Process., 2016, 107, 194205.

75 A. Martín, J. M. Arsuaga, N. Roldán, J. de Abajo, A. Martínez and A. Sotto, Desalination, 2015, 357, 16-25.

76 Q. Li, S. Pan, X. Li, C. Liu, J. Li, X. Sun, J. Shen, W. Han and L. Wang, Colloids Surf., A, 2015, 487, 180-189.

$77 \mathrm{H}$. Yu, X. Zhang, Y. Zhang, J. Liu and H. Zhang, Desalination, 2013, 326, 69-76.

78 A. Moezzi, A. M. McDonagh and M. B. Cortie, Chem. Eng. J., 2012, 185-186, 1-22.

79 B. Li, T. Liu, Y. Wang and Z. Wang, J. Colloid Interface Sci., 2012, 377, 114-121.

80 W. Hu, S. Chen, B. Zhou and H. Wang, Mater. Sci. Eng., B, 2010, 170, 88-92.

81 A. L. Ahmad, A. A. Abdulkarim, Z. M. H. Mohd Shafie and B. S. Ooi, Desalination, 2017, 403, 53-63.

82 L. Shen, X. Bian, X. Lu, L. Shi, Z. Liu, L. Chen, Z. Hou and K. Fan, Desalination, 2012, 293, 21-29.

83 J. Alam, L. A. Dass, M. Ghasemi and M. Alhoshan, Polym. Compos., 2013, 34, 1870-1877.

84 H. Rajabi, N. Ghaemi, S. S. Madaeni, P. Daraei, B. Astinchap, S. Zinadini and S. Hossein, Appl. Surf. Sci., 2015, 349, 66-77. 
85 I. Munnawar, S. S. Iqbal, M. N. Anwar, M. Batool, S. Tariq, N. Faitma, A. L. Khan, A. U. Khan, U. Nazar, T. Jamil and N. M. Ahmad, Carbohydr. Polym., 2017, 175, 661-670.

86 N. Nasrollahi, V. Vatanpour, S. Aber and N. Mohammad, Sep. Purif. Technol., 2018, 192, 369-382.

87 B. Li and Y. Wang, Superlattices Microstruct., 2010, 47, 615623.

88 J. F. Callejas, C. G. Read, C. W. Roske, N. S. Lewis and R. E. Schaak, Chem. Mater., 2016, 28, 6017-6044.

89 R. Pang, X. Li, J. Li, Z. Lu, X. Sun and L. Wang, Desalination, 2014, 332, 60-66.

90 N. Ghaemi, Appl. Surf. Sci., 2016, 364, 221-228.

91 K. Rambabu and S. Velu, Recent Advances in Chemical Engineering, 2014, vol. 6, pp. 4468-4470.

92 N. Ghaemi, S. S. Madaeni, P. Daraei, H. Rajabi, S. Zinadini, A. Alizadeh, R. Heydari, M. Beygzadeh and S. Ghouzivand, Chem. Eng. J., 2015, 263, 101-112.

93 P. Daraei, S. S. Madaeni, N. Ghaemi, M. A. Khadivi, B. Astinchap and R. Moradian, Sep. Purif. Technol., 2013, 109, 111-121.

94 M. Ahamed, M. S. AlSalhi and M. K. J. Siddiqui, Clin. Chim. Acta, 2010, 411, 1841-1848.

95 S. Iravani, H. Korbekandi, S. V Mirmohammadi and B. Zolfaghari, Res. Pharm. Sci., 2014, 9, 385-406.

96 X. Cao, M. Tang, F. Liu, Y. Nie and C. Zhao, Colloids Surf., B, 2010, 81, 555-562.

97 M. Sile-yuksel, B. Tas, D. Y. Koseoglu-imer and I. Koyuncu, Desalination, 2014, 347, 120-130.

98 H. Basri, A. F. Ismail and M. Aziz, Desalination, 2011, 273, 72-80.

99 A. Ananth, G. Arthanareeswaran, A. F. Ismail, Y. S. Mok and T. Matsuura, Colloids Surf., A, 2014, 451, 151-160.

100 C.-N. Yeh, K. Raidongia, J. Shao, Q.-H. Yang and J. Huang, Nat. Chem., 2015, 7, 166.

101 H. Huang, Y. Mao, Y. Ying, Y. Liu, L. Sun and X. Peng, Chem. Commun., 2013, 49, 5963-5965.

102 R. K. Joshi, P. Carbone, F. C. Wang, V. G. Kravets, Y. Su, I. V Grigorieva, H. A. Wu, A. K. Geim and R. R. Nair, Science, 2014, 343, 752-754.

103 F. Perreault, A. Fonseca de Faria and M. Elimelech, Chem. Soc. Rev., 2015, 44, 5861-5896.

104 L. L. Zhang, R. Zhou and X. S. Zhao, J. Mater. Chem., 2010, 20, 5983-5992.

105 T. A. Otitoju, A. L. Ahmad and B. S. Ooi, Journal of Water Process Engineering, 2016, 14, 41-59.

106 Y. Zhu, S. Murali, W. Cai, X. Li, J. W. Suk, J. R. Potts and R. S. Ruoff, Adv. Mater., 2010, 22, 3906-3924.

107 D. Fu, G. Han, Y. Chang and J. Dong, Mater. Chem. Phys., 2012, 132, 673-681.

108 M. Safarpour, A. Khataee and V. Vatanpour, Ind. Eng. Chem. Res., 2014, 53, 13370-13382.

109 J. R. Werber, C. O. Osuji and M. Elimelech, Nat. Rev. Mater., 2016, 1, 16018.

110 P. Sun, K. Wang and H. Zhu, Adv. Mater., 2016, 28, 2287-2310.

111 P. Fernández-Ibáñez, M. I. Polo-López, S. Malato, S. Wadhwa, J. W. J. Hamilton, P. S. M. Dunlop, R. D'Sa,
E. Magee, K. O'Shea, D. D. Dionysiou and J. A. Byrne, Chem. Eng. J., 2015, 261, 36-44.

112 Y. Han, Y. Jiang and C. Gao, ACS Appl. Mater. Interfaces, 2015, 7, 8147-8155.

113 Y. Zhang, S. Zhang and T.-S. Chung, Environ. Sci. Technol., 2015, 49, 10235-10242.

114 L. Yu, Y. Zhang, B. Zhang, J. Liu, H. Zhang and C. Song, J. Membr. Sci., 2013, 447, 452-462.

115 Z. Wang, H. Yu, J. Xia, F. Zhang, F. Li, Y. Xia and Y. Li, Desalination, 2012, 299, 50-54.

116 C. Zhao, X. Xu, J. Chen and F. Yang, J. Environ. Chem. Eng., 2013, 1, 349-354.

117 A. Abdel-Karim, S. Leaper, M. Alberto, A. Vijayaraghavan, X. Fan, S. M. Holmes, E. R. Souaya, M. I. Badawy and P. Gorgojo, Chem. Eng. J., 2018, 334, 789-799.

118 S. Zinadini, A. A. Zinatizadeh, M. Rahimi, V. Vatanpour and H. Zangeneh, J. Membr. Sci., 2014, 453, 292-301.

119 S. Aditya Kiran, Y. Lukka Thuyavan, G. Arthanareeswaran, T. Matsuura and A. F. Ismail, Chem. Eng. J., 2016, 286, 528-537.

120 J. Ma, X. Guo, Y. Ying, D. Liu and C. Zhong, Chem. Eng. J., 2017, 313, 890-898.

121 O. T. Mahlangu, R. Nackaerts, J. M. Thwala, B. B. Mamba and A. R. D. Verliefde, J. Membr. Sci., 2017, 524, 43-55.

122 J. Liu, A. G. Rinzler, H. Dai, J. H. Hafner, R. K. Bradley, P. J. Boul, A. Lu, T. Iverson, K. Shelimov, C. B. Huffman, F. Rodriguez-Macias, Y.-S. Shon, T. R. Lee, D. T. Colbert and R. E. Smalley, Science, 1998, 280, 1253-1256.

123 S. Iijima, Nature, 1991, 354, 56.

124 B. Sakintuna and Y. Yürüm, Ind. Eng. Chem. Res., 2005, 44, 2893-2902.

125 F. Peng, F. Pan, H. Sun, L. Lu and Z. Jiang, J. Membr. Sci., 2007, 300, 13-19.

126 J. H. Sung, H. S. Kim, H.-J. Jin, H. J. Choi and I.-J. Chin, Macromolecules, 2004, 37, 9899-9902.

127 Y. Lin, B. Zhou, K. A. Shiral Fernando, P. Liu, L. F. Allard and Y.-P. Sun, Macromolecules, 2003, 36, 7199-7204.

128 W.-X. Chen, J. Y. Lee and Z. Liu, Mater. Lett., 2004, 58, 31663169.

129 K. Kardimi, T. Tsoufis, A. Tomou, B. J. Kooi, M. I. Prodromidis and D. Gournis, Int. J. Hydrogen Energy, 2012, 37, 1243-1253.

130 A. I. López-Lorente, B. M. Simonet and M. Valcárcel, Anal. Chem., 2010, 82, 5399-5407.

131 M. A. Aroon, A. F. Ismail, M. M. Montazer-Rahmati and T. Matsuura, Sep. Sci. Technol., 2010, 45, 2287-2297.

132 B. Van der Bruggen, ISRN Nanotechnol., 2012, 2012, 1-17.

133 F. H. Gojny, M. H. G. Wichmann, U. Köpke, B. Fiedler and K. Schulte, Compos. Sci. Technol., 2004, 64, 2363-2371.

134 J. Zhu, H. Peng, F. Rodriguez-Macias, J. L. Margrave, V. N. Khabashesku, A. M. Imam, K. Lozano and E. V Barrera, Adv. Funct. Mater., 2004, 14, 643-648.

135 Q. Chen, R. Xu and D. Yu, Polymer, 2006, 47, 7711-7719.

136 N. Robertson and C. A. McGowan, Chem. Soc. Rev., 2003, 32, 96-103.

137 Y. Shirazi, M. A. Tofighy and T. Mohammadi, J. Membr. Sci., 2011, 378, 551-561. 
138 P. Calvert, Nature, 1999, 399, 210.

139 A. F. Ismail, N. H. Rahim, A. Mustafa, T. Matsuura, B. C. Ng, S. Abdullah and S. A. Hashemifard, Sep. Purif. Technol., 2011, 80, 20-31.

140 C. Oueiny, S. Berlioz and F. X. Perrin, Prog. Polym. Sci., 2014, 39, 707-748.

141 J. Choi, J. Jegal and W. Kim, J. Membr. Sci., 2006, 284, 406415.

142 A. L. Ahmad, M. Sarif and S. Ismail, Desalination, 2005, 179, 257-263.

143 L. Vast, Z. Mekhalif, A. Fonseca, J. B.Nagy and J. Delhalle, Compos. Sci. Technol., 2007, 67, 880-889.

$144 \mathrm{Y} . \mathrm{Hu}$ and C. Guo, IntechOpen, 2011.

145 H. T. Ham, C. M. Koo, S. O. Kim, Y. S. Choi and I. J. Chung, Macromol. Res., 2004, 12, 384-390.

146 C. S. Chen, X. H. Chen, L. S. Xu, Z. Yang and W. H. Li, Carbon, 2005, 43, 1660-1666.

147 H. Yu, X. Mo, J. Peng, M. Zhai, J. Li, G. Wei, X. Zhang and J. Qiao, Radiat. Phys. Chem., 2008, 77, 656-662.

148 P. Liu, Eur. Polym. J., 2005, 41, 2693-2703.

149 N. G. Sahoo, S. Rana, J. W. Cho, L. Li and S. H. Chan, Prog. Polym. Sci., 2010, 35, 837-867.

150 C.-H. Jung, D.-K. Kim and J.-H. Choi, Curr. Appl. Phys., 2009, 9, S85-S87.

151 P. Petrov, G. Georgiev, D. Momekova, G. Momekov and C. B. Tsvetanov, Polymer, 2010, 51, 2465-2471.

152 A. Liu, I. Honma, M. Ichihara and H. Zhou, Nanotechnology, 2006, 17, 2845.

153 L. Qu, Y. Lin, D. E. Hill, B. Zhou, W. Wang, X. Sun, A. Kitaygorodskiy, M. Suarez, J. W. Connell, L. F. Allard and Y.-P. Sun, Macromolecules, 2004, 37, 6055-6060.

154 A. Eitan, K. Jiang, D. Dukes, R. Andrews and L. S. Schadler, Chem. Mater., 2003, 15, 3198-3201.

155 K. Balasubramanian and M. Burghard, Small, 2005, 1, 180192.

156 J. Li, T. Tang, X. Zhang, S. Li and M. Li, Mater. Lett., 2007, 61, 4351-4353.

157 K.-W. Lee, B.-K. Seo, S.-T. Nam and M.-J. Han, Desalination, 2003, 159, 289-296.

158 A. G. Osorio, I. C. L. Silveira, V. L. Bueno and C. P. Bergmann, Appl. Surf. Sci., 2008, 255, 2485-2489.

159 J.-H. Choi, J. Jegal and W.-N. Kim, J. Membr. Sci., 2006, 284, 406-415.

160 G. Vuković, A. Marinković, M. Obradović, V. Radmilović, M. Čolić, R. Aleksić and P. S. Uskoković, Appl. Surf. Sci., 2009, 255, 8067-8075.

161 J. Shen, W. Huang, L. Wu, Y. Hu and M. Ye, Mater. Sci. Eng., A, 2007, 464, 151-156.

162 J. Kathi, K.-Y. Rhee and J. H. Lee, Composites, Part A, 2009, 40, 800-809.

163 S. W. Kim, T. Kim, Y. S. Kim, H. S. Choi, H. J. Lim, S. J. Yang and C. R. Park, Carbon, 2012, 50, 3-33.

164 C.-M. Chang and Y.-L. Liu, Carbon, 2010, 48, 1289-1297.

165 K. T. Kim and W. H. Jo, Carbon, 2011, 49, 819-826.

166 T. Knoell, J. Safarik, T. Cormack, R. Riley, S. W. Lin and H. Ridgway, J. Membr. Sci., 1999, 157, 117-138.

167 H. L. Zhang, eXPRESS Polym. Lett., 2012, 6, 620-628.
168 E. Celik, H. Park, H. Choi and H. Choi, Water Res., 2011, 45, 274-282.

169 S. Qiu, L. Wu, X. Pan, L. Zhang, H. Chen and C. Gao, J. Membr. Sci., 2009, 342, 165-172.

170 R. Levenstein, D. Hasson and R. Semiat, J. Membr. Sci., 1996, 116, 77-92.

171 C. Van Chung, N. Q. Buu and N. H. Chau, Sci. Technol. Adv. Mater., 2005, 6, 246-250.

172 L. Wang, X. Song, T. Wang, S. Wang, Z. Wang and C. Gao, Appl. Surf. Sci., 2015, 330, 118-125.

173 G. Kaminska, J. Bohdziewicz, J. I. Calvo, P. Prádanos, L. Palacio and A. Hernández, J. Membr. Sci., 2015, 493, 66-79.

174 P. Daraei, S. S. Madaeni, N. Ghaemi, M. A. Khadivi, B. Astinchap and R. Moradian, J. Membr. Sci., 2013, 444, 184-191.

175 T. A. Otitoju, A. L. Ahmad and B. S. Ooi, J. Polym. Res., 2017, 24, 1-11.

176 V. Vatanpour, M. Esmaeili and M. H. D. A. Farahani, J. Membr. Sci., 2014, 466, 70-81.

177 Y. Mansourpanah, S. S. Madaeni, A. Rahimpour, M. Adeli, M. Y. Hashemi and M. R. Moradian, Desalination, 2011, 277, 171-177.

178 R. Sengur, C. F. de Lannoy, T. Turken, M. Wiesner and I. Koyuncu, Desalination, 2015, 359, 123-140.

179 V. Vatanpour, S. S. Madaeni, R. Moradian, S. Zinadini and B. Astinchap, J. Membr. Sci., 2011, 375, 284-294.

180 E. Celik, L. Liu and H. Choi, Water Res., 2011, 45, 52875294.

181 M. Irfan, A. Idris, N. M. Yusof, N. F. M. Khairuddin and H. Akhmal, J. Membr. Sci., 2014, 467, 73-84.

182 W. Wang, L. Zhu, B. Shan, C. Xie, C. Liu, F. Cui and G. Li, J. Membr. Sci., 2018, 548, 459-469.

183 V. Vatanpour, S. S. Madaeni, R. Moradian, S. Zinadini and B. Astinchap, Sep. Purif. Technol., 2012, 90, 69-82.

184 S. Zinadini, S. Rostami, V. Vatanpour and E. Jalilian, J. Membr. Sci., 2017, 529, 133-141.

185 P. Daraei, S. S. Madaeni, N. Ghaemi, H. Ahmadi Monfared and M. A. Khadivi, Sep. Purif. Technol., 2013, 104, 32-44.

186 S. Al Aani, V. Gomez, C. J. Wright and N. Hilal, Chem. Eng. J., 2017, 326, 721-736.

187 J. Lee, Y. Ye, A. J. Ward, C. Zhou, V. Chen, A. I. Minett, S. Lee, Z. Liu, S. R. Chae and J. Shi, Sep. Purif. Technol., 2016, 163, 109-119.

188 M. L. Masheane, L. N. Nthunya, S. P. Malinga, E. N. Nxumalo, B. B. Mamba and S. D. Mhlanga, Sep. Purif. Technol., 2017, 184, 79-87.

189 M. Peydayesh, T. Mohammadi and O. Bakhtiari, Sep. Purif. Technol., 2018, 194, 488-502.

190 R. Saranya, G. Arthanareeswaran and D. D. Dionysiou, Chem. Eng. J., 2014, 236, 369-377.

191 Y. Zhang, Y. Chen, H. Zhang, B. Zhang and J. Liu, J. Inorg. Biochem., 2013, 118, 59-64.

192 R. Zhai, B. Zhang, Y. Wan, C. Li, J. Wang and J. Liu, Chem. Eng. J., 2013, 214, 304-309.

193 Y. Wang, J. Zhu, G. Dong, Y. Zhang, N. Guo and J. Liu, Sep. Purif. Technol., 2015, 150, 243-251. 
194 S. R. Levis and P. B. Deasy, Int. J. Pharm., 2002, 243, 125134.

195 E. Joussein, S. Petit, J. Churchman, B. Theng, D. Righi and B. Delvaux, Clay Miner., 2005, 40, 383-426.

196 M. Liu, B. Guo, M. Du and D. Jia, Appl. Phys. A, 2007, 88, 391-395.

197 H. Ismail, P. Pasbakhsh, M. N. A. Fauzi and A. Abu Bakar, Polym. Test., 2008, 27, 841-850.

198 P. Luo, Y. Zhao, B. Zhang, J. Liu, Y. Yang and J. Liu, Water Res., 2010, 44, 1489-1497.

199 R. Zhai, B. Zhang, L. Liu, Y. Xie, H. Zhang and J. Liu, Catal. Commun., 2010, 12, 259-263.

200 Y. Chen, Y. Zhang, J. Liu, H. Zhang and K. Wang, Chem. Eng. J., 2012, 210, 298-308.

201 J. Zhu, N. Guo, Y. Zhang, L. Yu and J. Liu, J. Membr. Sci., 2014, 465, 91-99.

202 Z. Wang, H. Wang, J. Liu and Y. Zhang, Desalination, 2014, 344, 313-320.

203 Y. Chen, Y. Zhang, H. Zhang, J. Liu and C. Song, Chem. Eng. J., 2013, 228, 12-20.

204 H. Yu, Y. Zhang, X. Sun, J. Liu and H. Zhang, Chem. Eng. J., 2014, 237, 322-328.

205 S. L. James, Chem. Soc. Rev., 2003, 32, 276-288.

206 J. L. C. Rowsell and O. M. Yaghi, Microporous Mesoporous Mater., 2004, 73, 3-14.

207 G. Ferey, Chem. Soc. Rev., 2008, 37, 191-214.

208 G. S. Papaefstathiou and L. R. MacGillivray, Coord. Chem. Rev., 2003, 246, 169-184.

209 S. Sorribas, P. Gorgojo, C. Téllez, J. Coronas and A. G. Livingston, J. Am. Chem. Soc., 2013, 135, 15201-15208.

210 D. Zacher, O. Shekhah, C. Woll and R. A. Fischer, Chem. Soc. Rev., 2009, 38, 1418-1429.

211 H. Furukawa, K. E. Cordova, M. O'Keeffe and O. M. Yaghi, Science, 2013, 341, 6149.

212 S. Keskin and S. Kızılel, Ind. Eng. Chem. Res., 2011, 50, 1799-1812.

213 J. Ma, Y. Ying, Q. Yang, Y. Ban, H. Huang, X. Guo, Y. Xiao, D. Liu, Y. Li, W. Yang and C. Zhong, Chem. Commun., 2015, 51, 4249-4251.

214 J. Ma, Y. Ying, X. Guo, H. Huang, D. Liu and C. Zhong, J. Mater. Chem. A, 2016, 4, 7281-7288.

215 T. Rodenas, M. Van Dalen, E. García-Pérez, P. Serra-Crespo, B. Zornoza, F. Kapteijn and J. Gascon, Adv. Funct. Mater., 2014, 24, 249-256.

216 Y. Peng, Y. Li, Y. Ban, H. Jin, W. Jiao, X. Liu and W. Yang, Science, 2014, 346, 1356-1359.

217 A. Huang, W. Dou and J. Caro, J. Am. Chem. Soc., 2010, 132, 15562-15564.

218 J. R. Li, J. Sculley and H. C. Zhou, Chem. Rev., 2012, 112, 869-932.

219 Q. Zhang, Y. Liu, Y. Su, R. Zhang, L. Fan, Y. Liu, T. Ma and Z. Jiang, RSC Adv., 2016, 6, 35532-35538.

220 M. S. Denny Jr., J. C. Moreton, L. Benz and S. M. Cohen, Nat. Rev. Mater., 2016, 1, 16078.
221 O. K. Farha, A. Özgür Yazaydın, I. Eryazici, C. D. Malliakas, B. G. Hauser, M. G. Kanatzidis, S. T. Nguyen, R. Q. Snurr and J. T. Hupp, Nat. Chem., 2010, 2, 944.

222 W. Xuan, C. Zhu, Y. Liu and Y. Cui, Chem. Soc. Rev., 2012, 41, 1677-1695.

223 T. Loiseau, C. Serre, C. Huguenard, G. Fink, F. Taulelle, M. Henry, T. Bataille and G. Férey, Chem.-Eur. J., 2004, 10, 1373-1382.

224 F. Gholami, S. Zinadini, A. A. Zinatizadeh and A. R. Abbasi, Sep. Purif. Technol., 2018, 194, 272-280.

225 Z. X. Low, A. Razmjou, K. Wang, S. Gray, M. Duke and H. Wang, J. Membr. Sci., 2014, 460, 9-17.

226 R. Ranjan and M. Tsapatsis, Chem. Mater., 2009, 21, 49204924.

227 G. Lu and J. T. Hupp, J. Am. Chem. Soc., 2010, 132, 78327833.

228 E. Biemmi, C. Scherb and T. Bein, J. Am. Chem. Soc., 2007, 129, 8054-8055.

229 S. Hermes, F. Schröder, R. Chelmowski, C. Wöll and R. A. Fischer, J. Am. Chem. Soc., 2005, 127, 13744-13745.

230 S. Keskin and D. S. Sholl, J. Phys. Chem. C, 2007, 111, 1405514059.

231 J. H. Cavka, S. Jakobsen, U. Olsbye, N. Guillou, C. Lamberti, S. Bordiga and K. P. Lillerud, J. Am. Chem. Soc., 2008, 130, 13850-13851.

232 R. Jamshidi Gohari, E. Halakoo, N. A. M. Nazri, W. J. Lau, T. Matsuura and A. F. Ismail, Desalination, 2014, 335, 8795.

233 Y. Orooji, M. Faghih, A. Razmjou, J. Hou, P. Moazzam, N. Emami, M. Aghababaie, F. Nourisfa, V. Chen and W. Jin, Carbon, 2017, 111, 689-704.

234 F. S. A. Negin Ghaemi and P. Daraei, Carbohydr. Polym., 2018, 2, 165-182.

235 O. A. Jimoh, P. U. Okoye, T. A. Otitoju and K. Shah Ariffin, J. Cleaner Prod., 2018, 195, 79-92.

236 Q. F. Alsalhy, H. A. Salih, S. Simone, M. Zablouk, E. Drioli and A. Figoli, Desalination, 2014, 345, 21-35.

237 Y. Kourde-hana, P. Loulergue, A. Szymczyk, B. Van Der Bruggen, M. Nachtnebel, M. Rabiller-baudry, J. Audic, P. Pölt and K. Baddari, J. Membr. Sci., 2017, 533, 261-269.

238 M. Son, H. Kim, J. Jung, S. Jo and H. Choi, Chemosphere, 2017, 179, 194-201.

239 S. A. Al Malek, M. N. Abu Seman, D. Johnson and N. Hilal, Desalination, 2012, 288, 31-39.

240 N. Maximous, G. Nakhla, W. Wan and K. Wong, J. Membr. Sci., 2010, 352, 222-230.

241 N. Maximous, G. Nakhla, W. Wan and K. Wong, J. Membr. Sci., 2009, 341, 67-75.

242 N. Maximous, G. Nakhla, K. Wong and W. Wan, Sep. Purif. Technol., 2010, 73, 294-301.

243 G. S. Lai, M. H. M. Yusob, W. J. Lau, R. Jamshidi Gohari, D. Emadzadeh, A. F. Ismail, P. S. Goh, A. M. Isloor and M. Rezaei-Dasht Arzhandi, Sep. Purif. Technol., 2017, 178, 113-121.

244 T. A. Otitoju, A. L. Ahmad and B. S. Ooi, Korean J. Chem. Eng., 2017, 34, 1-7. 